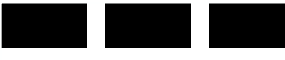 \\ F \\ ThE WILLIAM DAVIDSON INSTITUTE \\ AT THE UNIVERSITY OF MICHIGAN
}

\section{SUPPORTING AFRICA'S POST-CRISIS GROWTH: THE ROLE OF MACROECONOMIC POLICIES}

\author{
By: Zuzana Brixiová, Léonce Ndikumana \\ and KaoutherAbderrahim
}

William Davidson Institute Working Paper Number 1008 January 2011 


\title{
SUPPORTING AFRICA'S POST-CRISIS GROWTH: THE ROLE OF MACROECONOMIC POLICIES
}

\author{
Zuzana Brixiová and Léonce Ndikumana ${ }^{1}$ \\ African Development Bank, Development Research Department, Tunis, Tunisia \\ With contribution from Kaouther Abderrahim ${ }^{2}$
}

The objective of this paper is to discuss macroeconomic policies that would help African countries, especially the low income countries, reach strong, sustained and shared growth in the post-crisis world. The paper first reviews, with a special focus on LICs, macroeconomic policies in Africa prior to the crisis. It then discusses factors behind 'the Africa surprise' that is the continent's overall good performance during the crisis and relatively fast recovery. It underscores that in the aftermath of the crisis, the emphasis of the macroeconomic policy needs to shift from the objective of very low inflation that predominated prior to the crisis towards growth. Fiscal policy is key in this regard, through public outlays on infrastructure anchored in the medium term expenditure frameworks that would also have a counter-cyclical role. Where conditions allow, frontier market LICs may want to consider adopting flexible inflation targeting frameworks that would provide sufficient room for expansion of credit to the private sector.

JEL classification: E5, F43, O11, O47

Key words: macroeconomic policies, growth, capital flows, Africa

\footnotetext{
1 The authors are especially thankful to John Weeks for helpful comments. They also thank John Anyanwu, Abdul Kamara, Gil Seong Kang, Louis Kouakou, Willi Leibfritz, Mthuli Ncube, Barfur Osei, Abebe Shimeles, Neema Siwingwa, and Desiré Vencatachellum for insightful suggestions. Wadji Sfafi provided excellent research assistance. Earlier versions were presented at the conference on 'Impacts, Responses \& Initial Lessons of the Financial Crisis for Low Income Countries' (Copenhagen, October 2010) and at the seminar series at the African Development Bank. The views expressed are those of the authors and do not necessarily reflect those of the AfDB. E-mail addresses: z.brixiova@afdb.org; 1.ndikumana@,afdb.org; k.abderrahim@,afdb.org.

${ }^{2}$ Kaouther Abderrahim is a consultant in the Development Research Department, African Development Bank.
} 


\section{Introduction}

In the aftermath of the global financial and economic crisis, African policy makers have been rethinking their economic strategies for the next decade. ${ }^{3}$ Given the large share of lowincome countries (LICs) on the continent, poverty reduction still tops the policy agenda. At the same time, Africa's high pre-crisis growth and a quick rebound from the crisis have highlighted the continent's vast and so far mostly untapped economic potential. The key question then is how to turn Africa's potential into substantial and tangible improvements in people's living standards.

With Africa rebounding, the consensus has emerged that the key policy challenge ahead of African policy makers is to turn the effective responses to the crisis and the ongoing recovery into strong, sustained and shared growth over the medium term. Such growth is key for building a prosperous Africa. While by itself it is not sufficient to reduce poverty, without the increased resources that growth will generate, progress with the other non-income poverty development goals will be also jeopardized. And only growth that is shared - through creating decent jobs and social safety nets - can be sustained through steady and wide popular support for reforms.

The objective of this paper is to provide an overview of macroeconomic policies prior to the crisis and responses to the crisis in Africa, with a focus on LICs, and discuss policy options in the aftermath of the crisis. The paper is organized as follows. After this Introduction, Section II takes a rearview mirror looking at Africa's macroeconomic policies and performance during 2001-08. Section III covers Africa's overall surprising resilience during the crisis and discusses exit strategies from crisis interventions. Section IV outlines policies that would refocus the agenda from stabilization and very low inflation to strong, sustained and shared growth in the decade ahead. Section V concludes.

\section{Africa's growth in the rearview mirror (2001-08)}

\section{Growth and inflation outcomes}

At an average of 5.7 percent a year during 2001-08, Africa experienced its highest growth in decades. A combination of factors contributed to this strong performance. In addition to a favorable external environment, domestic factors such as reduced conflict, greater political stability, and prudent macroeconomic policies underpinned growth. A number of African LICs undertook structural reforms that improved the business environment (e.g., Rwanda, Ethiopia), the financial sector (Nigeria), administration, and governance (Sierra Leone). Moreover, increasing trade and investment flows between Africa and China, India and the Gulf countries are becoming an important driver of growth and a buffer against shocks.

The high growth was wide-spread across the continent, with about 40 percent of countries having grown above average of 5 percent a year. Both middle-income countries (MICs) and lowincome countries (LICs) grew at almost the same rates during this period. Nevertheless, differences in rates persisted across subgroups such as the oil exporters and the oil importers as well as between fragile LICs, frontier market LICs, transition LICs and the rest (Figure 1 and

\footnotetext{
${ }^{3}$ See Devarajan and Kasekende (2009).
} 
Table AI.1 in Annex I). Oil exporters, frontier market LICs and transition LICs grew faster than the others, reflecting both the favorable external environment and domestic reform efforts. ${ }^{4}$

Figure 1. Real GDP growth rates by Africa's sub-groups (annual, percent) 1/

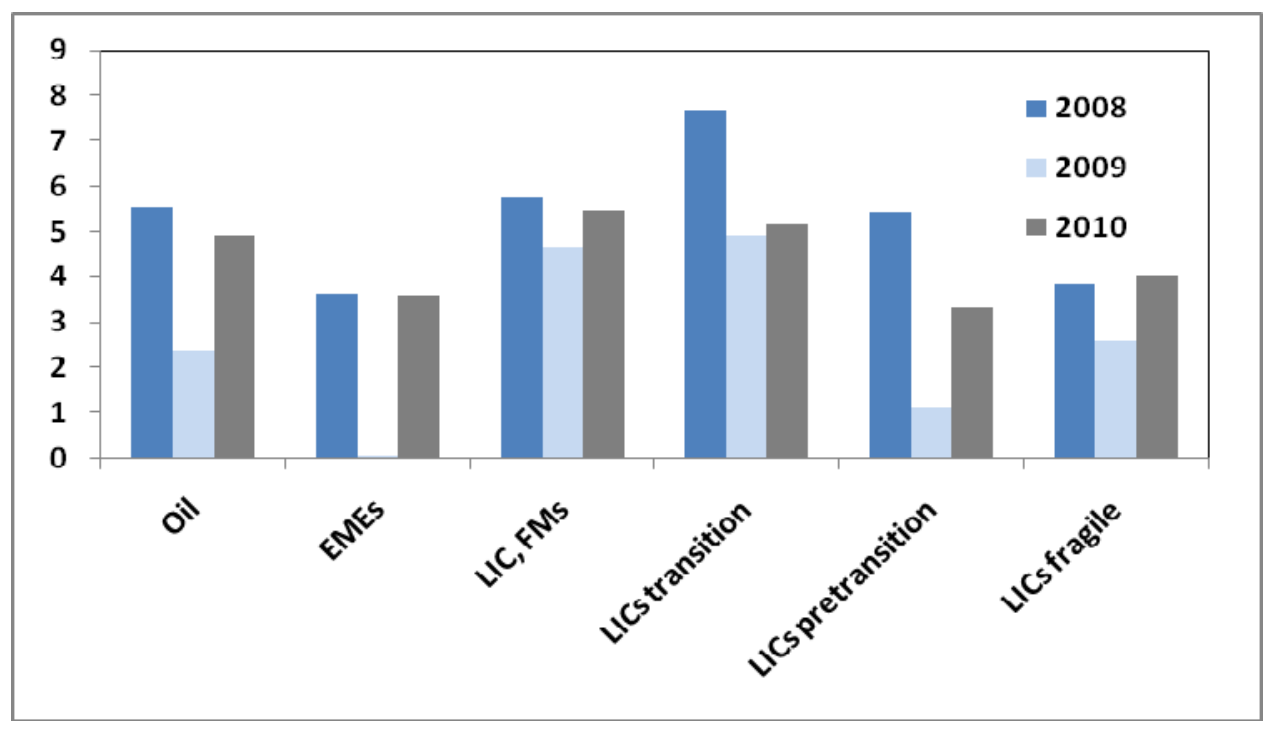

Source: Authors' calculations based on the African Economic Outlook database. 1/ EMEs denotes emerging market economies and FMs denotes frontier markets.

Africa's relatively high growth during 2001-08 was a positive turnaround, but it was still not high enough to initiate convergence to the living standards in advanced economies. Only about 25 percent of low-income countries (LICs) grew at 7 or more percent a year during this period. On the inflation side, about 40 percent of the LICs had inflation below 5 percent and 75 percent of them below 10 percent during 2001 - 08 (Figures AI.1.a and AI.1.b, Annex I). The overall reduction in inflation is a marked improvement from the 1990s when less than half of LICs had inflation below 10 percent. Most countries, ranging from frontier markets to fragile states, were able to establish a lower and more stable inflationary environment (Figure AI.2., Annex I). ${ }^{5}$ However, the high growth needed to improve people's lives has remained elusive for most African LICs.

Yet, in most cases, very low inflation rates (below 5 percent) are not appropriate inflation targets for LICs. While benefits to growth of bringing down high inflation are well documented, empirical evidence shows that for LICs inflation hampers growth only if it exceeds a certain threshold (typically 10-20 percent); the positive impact of reduced inflation on growth is

\footnotetext{
${ }^{4}$ This grouping of countries is based on income per capita, recent growth and medium-term growth prospects and the level of financial sector development. In that context, emerging market economies are for the most part middle income countries that have also accessed international capital markets and/or attracted the interest of foreign investors. Frontier markets exhibited substantial pre-crisis growth and resilience during the crisis, and also already have or are just about to access the international capital markets.

${ }^{5}$ Some countries recorded reductions in inflation rates from mid-double digits in the 1990s to low-single digits in the 2000s (e.g. Guinea Bissau) or further consolidated their stabilization gains by moving from high to low single digit inflation rates in 2000s (e.g., Cape Verde, Republic of Congo).
} 
insignificant below this threshold. Moreover, LICs that target very low inflation (say below 5 percent) can experience unintended contractionary effects in the event of shocks. ${ }^{6}$ At the same time, once inflation is stabilized at low level and expectations adjust, faster growth may be achieved without raising inflation. Put differently, LICs should not aim at very low inflation levels, with the threshold for 'very low' being often set at 5 percent or higher (IMF, 2005).

In sum, at least some of the LICs that achieved very low inflation rates may have done so at some cost in terms of their growth. Going forward in the aftermath of the crisis, African LICs have an opportunity to rethink their macroeconomic strategies and focus on growth. ${ }^{7}$

\section{Constraints to growth}

Despite the strong performance observed prior to the crisis, African countries still face key constraints to medium and long-term growth that need to be addressed through appropriate policy interventions. Africa has been characterized by relatively low savings rates, especially in comparison to developing Asia (Figure 2a and Table AI.2, Annex). Once again, the aggregate numbers hide important differences across countries and groups such as North and sub-Saharan Africa. While savings rates in North African countries increased rapidly during the pre-crisis commodity boom and as a result of financial sector development, ${ }^{8}$ they continued to be low in most SSA countries.

From another perspective, low savings are oil importers' Achilles heel. As many of the oil importing countries were unable to access international capital markets and did not attract much FDI, their investment rates were also low and relied on official aid. Long-standing factors such as low per capita income, low financial depth, high young-age dependency ratios, and aid dependency have contributed to low savings rates of this group, reinforced at times by conditions contributing to capital flight (e.g., weak investment climate).

Increasing domestic savings rates and reducing capital outflows, especially the illicit ones, continue to be key policy challenges for this group. ${ }^{9}$ On the positive side, policy makers are able to impact public saving rates through measures geared towards resource mobilization and improved efficiency of government spending. On the other hand, private savings rates tend to be persistent, with changes in their determinants exhibiting full impact only after a number of years (Loayza, Schmidt-Hebbel, and Serven, 2000).

\footnotetext{
${ }^{6}$ Nigeria is a good example in this regard. With current (August 2010) inflation above 10 percent, the Central Bank aims at reducing it to 9.5 percent but not lower, stating that growth is the key priority.

${ }^{7}$ Collier (2007) pointed out that it was not clear to what extent the latest boom in the region was driven by improved commodity prices. However, some of the fastest growing countries (Ethiopia, Rwanda, Tanzania) are resource poor and introduced important structural reforms prior to the crisis, in addition to improved macroeconomic management.

${ }^{8}$ In these countries, saving and investment rates were below those in Asia. Some countries (e.g. Morocco) recorded asset booms prior to the crisis, with private investment going to non-tradable sectors. Overall, data on private savings rates is limited.

${ }^{9}$ Savings matters for growth and innovation, notably by allowing domestic and foreign investors to engage in joint ventures (Aghion, 2009). Elbadawi and Mwega (2000) cover the causes of low savings rates in SSA, while Ndikumana and Boyce (2010) discuss capital flight from SSA countries.
} 
Oil exporters face different challenges. Despite higher savings rates (about 35 percent in 2005-08), in the last few years prior to the crisis their investment rates were close, and private investment rates even below, those of oil importers (Figure 2). This suggests that export proceeds were not used for enhancing productive capacity and competitiveness. Export proceeds and the accumulated foreign exchange reserves thus need to be better managed to maximize their development impact (Figure AI.3.a, Annex I).

The conduct of monetary policy with fluctuating oil revenues also presents a challenge. Specifically, with rising revenues during the commodity boom, oil exporters' deposit bases expanded and growth of credit to the private sector escalated. Subsequently, it declined markedly during the global financial crisis when commodity revenues plummeted, underscoring the importance of diversification (Figure A.3.b, Annex I). ${ }^{10}$

Figure 2a. Africa and Developing Asia: National Savings and Investment Rates (\% of GDP)

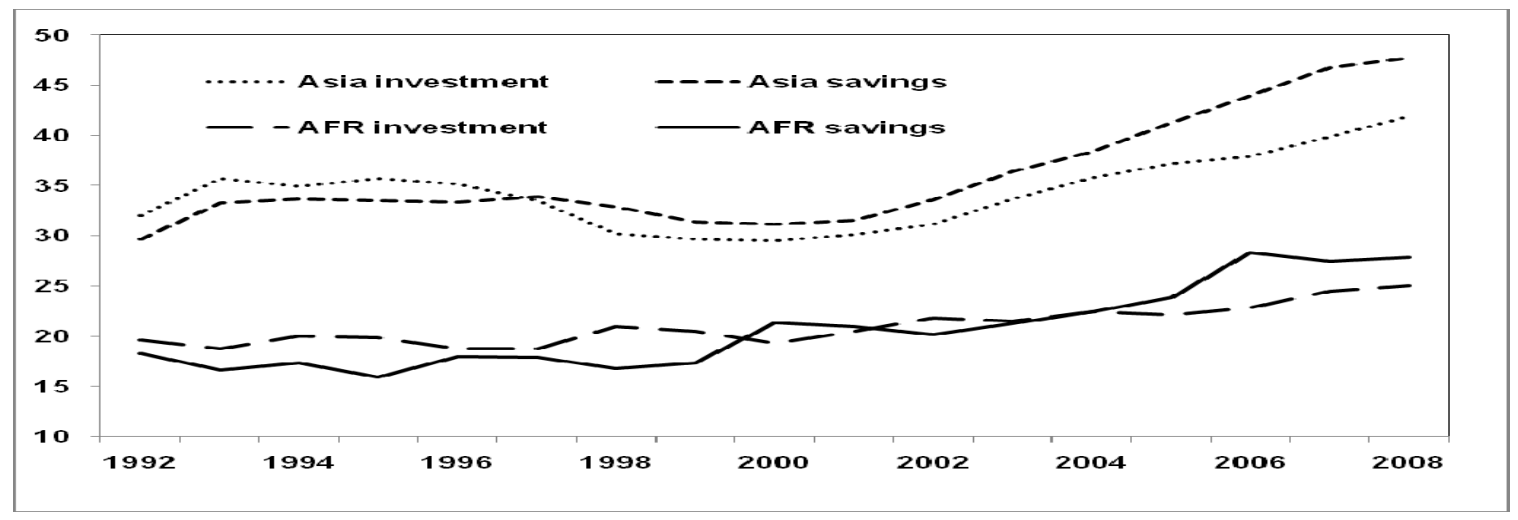

Figure 2b. African Oil Exporters and Importers: Total and Private Investment Rates (\% of GDP)

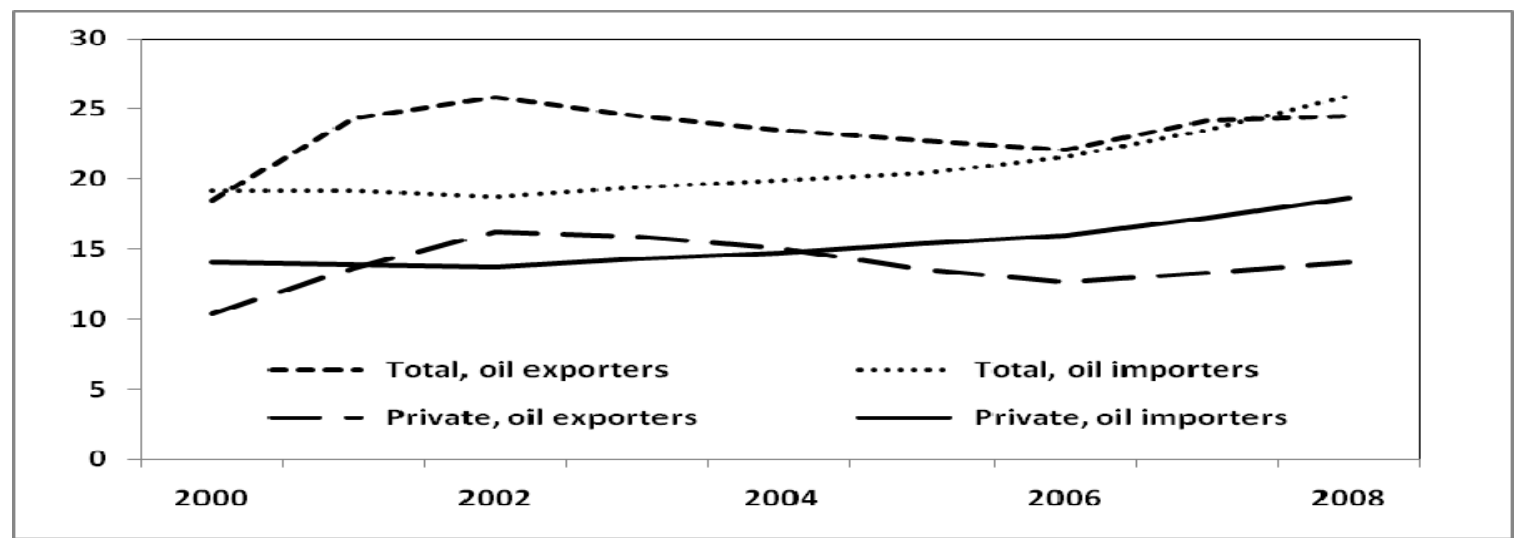

Source: Arican Economic Outlook database and IMF WEO database.

\footnotetext{
${ }^{10}$ As the global financial and economic crisis once again illustrated, undiversified, low value-added exports, lead to large volatility of proceeds, reiterating that greater diversification is needed both in terms of products and trade partners, including deepening South-South and regional trade and investment ties.
} 
African countries in general, and LICs in particular, also face a range of other structural constraints that undermine competitiveness, private sector development, and growth. Key among these are the infrastructure deficits that raise production and trade costs, rigid regulatory frameworks that discourage entrepreneurship, and weak market integration at national and subregional level that limit the flow of goods and services while also limiting the gains from economies of scale. These constraints existed before the crisis and they will need to feature centrally in the national strategies aimed at unlocking the potential of the private sector and promoting diversification of the economic base as a means of laying the foundation for higher, sustained and share growth.

\section{Growth drivers}

\section{Sources of aggregate demand}

Different factors drove aggregate demand across countries. Among the oil exporters, frontier markets and transition LICs, demand was driven largely by exports, while in the rest of the countries it was domestic demand-driven (Table 1). In the emerging markets, private consumption increased markedly during $2001-08$, in some cases also in part due to the asset boom. The rising share of private investment in GDP in most subgroups (except oil exporters) is a positive development since it went mostly into productive capital and infrastructure, building a base for future growth. ${ }^{11}$

Table 1. Changes in Domestic Demand in Africa, 2001- 08, percent of GDP

\begin{tabular}{lrrrrrrr}
\hline & $\begin{array}{c}\text { Domestic } \\
\text { Demand }\end{array}$ & \multicolumn{3}{c}{ Consumption/GDP } & \multicolumn{3}{c}{ Investment/GDP } \\
& 2.3 & -0.5 & -1.2 & 0.8 & 2.8 & 3.6 & -0.8 \\
\hline Africa & & & & & & & \\
& -6.7 & -3.4 & -3.4 & -0.1 & -3.3 & -4.8 & 1.5 \\
Oil exporters & 8.8 & 2.3 & 7.6 & -5.3 & 6.5 & 5.4 & 1.1 \\
Emerging markets & -3.2 & -4.4 & -4.6 & 0.2 & 1.1 & 3.4 & -2.3 \\
LICs, frontier markets & -0.8 & -3.5 & -8.4 & 4.8 & 2.7 & 7.9 & -5.2 \\
LICs, transition countries & 9.2 & 1.8 & -1.2 & 3.0 & 7.4 & 8.3 & -0.9 \\
LICs, pre-transition & 14.4 & 7.1 & 2.2 & 4.9 & 7.3 & 9.1 & -1.8 \\
LICs, fragile 1/ & &
\end{tabular}

Sources: Authors' calculations based on African Economic Outlook database (un-weighted averages). 1/ If Liberia were excluded, demand for this group would be driven mostly by domestic consumption. .

\section{Rising private capital flows: magnitudes and impacts}

As many African countries are small open economies with low savings rates and/or volatile exports, capital flows - especially private capital flows recently - also fueled growth. While developed economies continue to account for the majority of the world FDI flows - they are the main source of outward FDI and receive about 70 per cent of the total inflows of FDI and the long-term geographical pattern of the FDI flows has been gradually changing towards developing countries including in Africa.

\footnotetext{
11 This approach considers a short-term to medium-term horizon, where consumption (and aggregate demand) can stimulate output. Over the longer term, where both consumption and imports are functions of output $(\mathrm{c}=\mathrm{c}(\mathrm{y})$ and $\mathrm{z}$ $=\mathrm{z}(\mathrm{y}))$, the relative shares of the drivers changes and exports are a key driver of growth.
} 
In recent years, the net private capital flows to Africa (FDI) exceeded several times official flows. Specifically, after years of relatively slow growth, net private capital inflows to African countries accelerated in the early 2000s and surged between 2004 and 2007, reaching about $\$ 30$ billion (slightly above $3 \%$ of Africa's GDP) in 2007, while official flows amounted to only $\$ 6$ billion that year (Figure 3). The surge of private capital flows to Africa reflects both increased risk appetite of foreign investors searching for new profit opportunities, as well as the success of macroeconomic and structural reforms in many African countries. ${ }^{12}$

The analysis of the components of private capital flows to North Africa and SSA prior to the crisis reveals that in both groups FDI accounted for the lion's share of the total flows, with North Africa having received about 30 percent of total FDI going to the continent. However, FDI has been distributed unevenly even within Africa; the top five recipient countries received the bulk of FDI inflows to Africa during 2001 - 2008. Resource rich countries and the mineral sectors attracted the main share of these flows, but more recently investors have discovered countries other than Angola, Nigeria, and South Africa, their traditional preferred destinations. Since mid-2000s, frontier market countries such as Ghana, Uganda, and Zambia have attracted increased FDI. As far as non-mining sectors, services - especially telecommunications and banking - have been receiving disproportionate shares of FDI (Figure A.4).

Figure 3. Net private capital flows to Africa, 1981 - 2008 (in \$ billions)

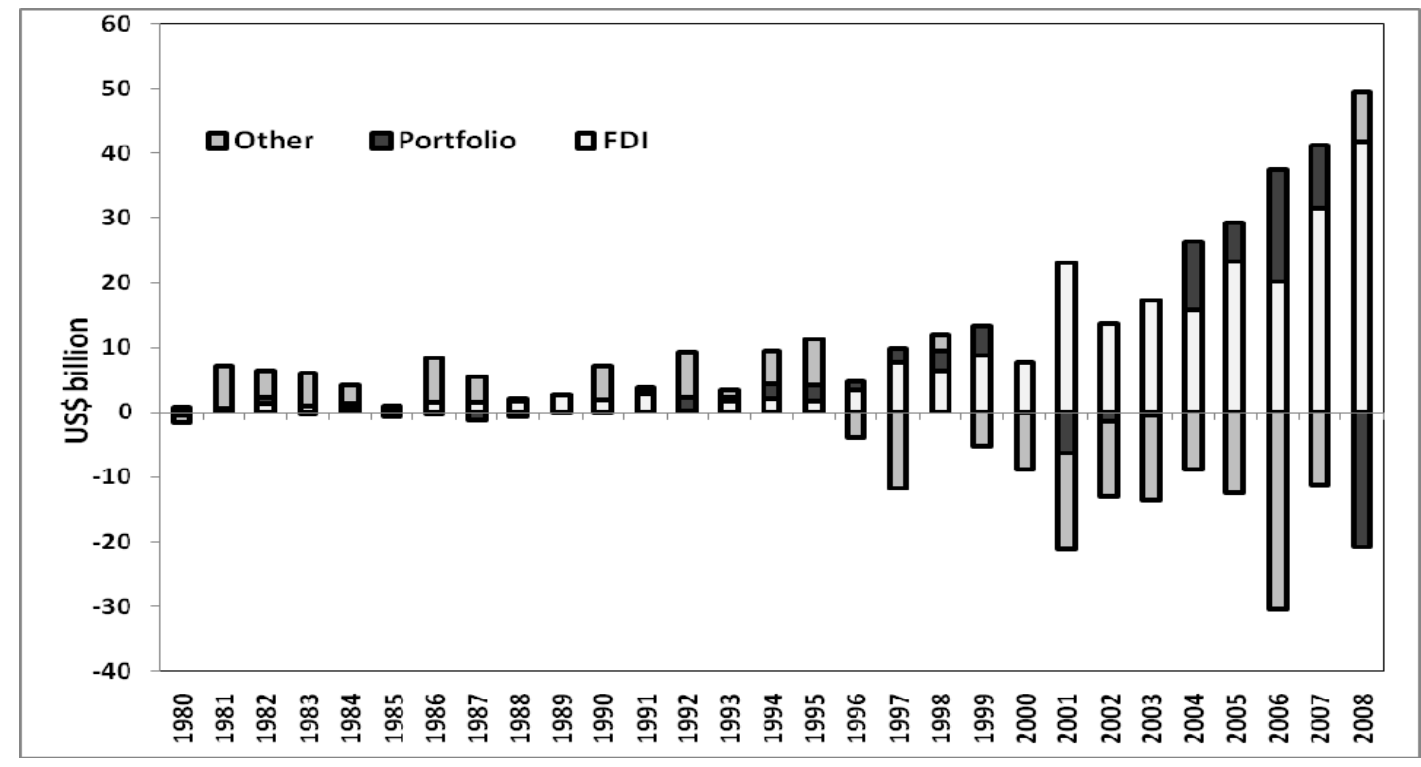

Source: IMF WEO database.

In addition to the FDI destinations, the sources of FDI have also changed during the past two decades, with the rising importance of Southern investors, especially from Asia. At the end of 2008, all top five 'South' investors in Africa were from Asia: China's stock of FDI in Africa

\footnotetext{
${ }^{12}$ Over the period, private capital flows to Africa and growth in advanced economies are negatively correlated, suggesting that the business cycles in advanced economies play a role in the availability of capital for the continent. Moreover, the share of Africa's FDI in the FDI flows to emerging market and developing countries remains constant throughout the period, pointing to general increase of investors' interest in developing countries.
} 
amounted to over $\$ 13$ billion, followed by Singapore ( $\$ 9.8$ billion), Malaysia ( $\$ 3.7$ billion), India ( $\$ 2.7$ billion), and Korea ( $\$ 0.5$ billion) (UNCTAD, 2009). At about 5 percent of total FDI inflows, the share of African investment on the continent remained almost unchanged and well below that of intra-regional investment in other regions. Still, intra-African FDI flows constitute an important source of investment funds in several countries, especially in Southern Africa (e.g. Mauritius, Mozambique), with South Africa being the main investor (Figure A.4.c).

While often beneficial, the impact of FDI on productivity and growth remains limited in most countries. For example, among several West African countries (Cape Verde, Ghana, Senegal, Nigeria) and Egypt during 1987 - 2008, FDI generated positive technological spillovers only in Cape Verde and Egypt. In Senegal and Ghana, the positive impact on FDI on growth occurred through capital accumulation and increased the marginal product of capital, while in Nigeria, FDI did not seem to have any significant impact at the aggregate level, although some specific sectors may have benefited (Annex II).

The observation that FDI would be more beneficial for growth in more developed economies is consistent with the literature on the need to establish necessary threshold conditions for FDI to have a positive impact on growth. Specifically, empirical evidence suggests that some minimal threshold of development is needed for the host countries to benefit from FDI (Borenzstein et al., 1998; Alfaro et al., 2004; Wang and Wong, 2009). Put differently, if the institutional, technological and human capital gaps with the investor's country are wide, the host country will lack capacity to absorb the technological and 'know-how' transfers. Efforts to raise human capital and technological capacity are therefore key to reaping development benefits from FDI.

More broadly, the positive impact of FDI on growth and development of host countries is unlikely to materialize unless the other participants in this process, e.g. multinational enterprises, the sending countries and the international community, implement supporting policies. For example, given that trade and FDI reinforce each other and some FDI is even contingent on trade, further trade liberalization in sending countries would be FDI-enhancing. Equally important is that sending companies take into account technological priorities of recipient countries, and where feasible 'clean' technologies, to facilitate sustainable development. As OECD (2002) points out, MNEs have a key role to play by utilizing adequate technology, sharing knowledge, and adhering to good standards of corporate behavior.

\section{Capital flows and savings in Africa: complements or substitutes?}

While the link between capital flows (foreign savings) and domestic savings has been extensively examined for emerging market regions (e.g. Latin America, Asia, and emerging Europe), it has been relatively understudied for Africa and especially SSA, because of the lower private capital flows that the region has received in the past. With increased private inflows, the issue has gained in importance, especially in light of the implicit vulnerability to 'sudden stops'.

The short run responses of saving rates to capital flows in Africa during 1980-2008, measured by the pair-wise correlation between their cyclical components are presented in Table 
$2 .^{13}$ The positive correlation points to complementarity between capital flows and savings; when it is negative, they are substitutes. Two observations stand out. First, the correlation between domestic saving and capital flows (foreign savings) is negative in SSA and positive in North Africa, suggesting that these are substitutes in the former and complements in the latter. Second, correlation between cyclical components of capital flows to North Africa and SSA was positive, suggesting that common external shocks determined capital inflows.

Together, these observations point to different macroeconomic policy responses to capital flows in these sub-regions, with North Africa being able to raise investment rates substantially more than SSA during the 2000s, albeit still less than in developing Asia. However, this does not imply that SSA has only raised its consumption. Historically (from $1965-2006$ ), only about 65 percent of increased official capital flows relative to output in SSA was used for either consumption (41 percent) or investment (24 percent). The remaining portion of increased aid inflows financed outflows such as debt repayment, reserve accumulation and capital flight (Serieux, 2009). During 2000s, the outflows from SSA amounting to US\$358 billion markedly exceeded that from North Africa of US\$79 billion (Ker and Cartwright-Smith, 2010). The amount of illicit capital outflows from SSA and the acceleration of this trend during 2000s need to be addressed (see Ndikumana and Boyce, 2010).

Table 2. Africa: Co-movements of savings and net capital flows, $1980-2008$ 1/

\begin{tabular}{lcc}
\hline & $\begin{array}{c}\text { HP filter } \\
\text { correlation }\end{array}$ & $\begin{array}{c}\text { Band pass filter } \\
\text { correlation }\end{array}$ \\
\hline Africa & -0.141 & $-0.362^{\star}$ \\
SSA & $-0.444^{*}$ & $-0.59^{\star}$ \\
North Africa & $0.396^{*}$ & 0.307 \\
Low incomes countries 2/ & -0.362 & $-0.496^{\star}$ \\
\hline
\end{tabular}

Source: Authors' calculations based on the African Development Bank database and the IMF WEO database. 1/* Denotes significance at 10 percent level. 2/ Denoted countries eligible for concessional financing from the AfDB.

\section{Comparing pre-crisis macroeconomic paths of Africa and developing Asia}

In the ongoing development debate, Asia has often been an example of success that Africa could possibly follow, including in the areas of macroeconomic management and private sector development. Moreover, the low saving and investment rates, together with even more limited access to credit in the aftermath of the crisis, have raised questions whether African countries can reach high and sustainable long run growth. ${ }^{14}$ It is thus worthwhile to examine the key differences in the chosen macroeconomic and development paths during 2000s, with a view of identifying elements and policies that Africa could apply regardless of these differences.

\footnotetext{
${ }^{13}$ The approach of Reinhart and Talvi (1998) is adopted. Annual data on savings rates and capital flows during 1980 - 2008 are used and decomposed into their trend (permanent) and cyclical (temporary) components, using the HP and the band pass filters.

${ }^{14}$ According to the Solow growth model, technological progress is the only diver of the long-run growth, while investment plays a role only in transition. Since SSA economies are not in the steady state, investment rates matter.
} 
Disparities in policies and outcomes among Africa's subgroups notwithstanding, several observations can be made about the development paths undertaken by Africa and developing Asia. Asian economies in 2000s were characterized by high domestic (national) savings rates, active FDI policy, very low foreign debt, and -as a reaction to the Asian crisis - rapidly rising foreign exchange reserves. In contrast, due to limited domestic revenue mobilization, African economies exhibited lower savings rates and hence smaller room for domestic investment. This, in turn, led to greater dependency on foreign capital. Moreover, Asian economies have created a strong capacity to export manufacturing goods, which is almost absent in Africa where exports are dominated by primary commodities and low value-added products. ${ }^{15}$

More broadly, on the spectrum of possible development paths, during 2000s Africa was notably closer than developing Asia to the "Washington Consensus". This approach emphasized trade and FDI liberalization, deregulation and privatization, and reducing the role of the state in the economy. Much of this choice by African countries was driven by the financial arrangements with the IMF and the World Bank and especially by the debt relief initiatives. Still, in many ways, the reforms adopted during this period served Africa well, as the increased pre-crisis growth and the continent's resilience during the global crisis illustrated. Regarding structural reforms such as improving governance and removing barriers to competition, Africa still lags behind other regions, underscoring the importance of further reforms.

An open question also remains whether the objective of macroeconomic stability, in particular low inflation, was overemphasized among Africa's economic policies at the expense of measures that stimulate growth and accelerate poverty reduction (as suggested above). More recently, policy makers all over the world recognized, and the impact of the global financial crisis reinforced, that the state has an important role to play in development, beyond creating an enabling environment for businesses and providing basic social services. The departure of the prevailing development paradigm from excessive emphasis on the market was in part due to the positive role of state interventions in growth promotion in Asia.

In sum, even though during the run up to the crisis Africa reached its highest growth rates in decades, the rates were still below those recorded by developing Asia. Africa's growth was not only lower, but also more volatile than that of Asia. Moreover, where high growth was achieved, it often brought about widening inequalities, as many African countries are still missing indigenous industries, in particular manufacturing, or highly productive services. Correspondingly, political room to pursue social policies, including building adequate social safety nets, was also limited. Key factors behind these different development paths have been (i) notably lower saving rates in Africa than in Asia, especially among its oil importers; and (ii) volatile and low-value added exports of oil exporters. These factors contributed to Africa's dependence on external environment including official aid and exports markets, and made the continent vulnerable to external shocks.

\footnotetext{
${ }^{15}$ Regarding similarities, African oil and commodity exporters also accumulated high reserves (albeit lower than in Asia) during the commodity boom, underscoring the importance of appropriate management of reserves.
} 


\section{Impact of the crisis on Africa and the exit strategies ${ }^{16}$}

\section{a. The Africa surprise}

\section{Overall impact of the crisis}

In 2009, Africa's high growth was interrupted by a severe external shock in the form of the global financial and economic crisis. Most African countries were hit hard through the real channels such as declining exports and FDI and in some cases also aid, remittances and tourism receipts. Subsequently, in 2009 most key macroeconomic indicators deteriorated. Real GDP grew on average by only 2.5 percent, but the performance varied from 6.8 percent decline (Seychelles) to 9.9 percent growth (Ethiopia). The impact on SSA was severe, as growth collapsed from an average of 6.1 percent during 2001-08 to 1.6 percent in 2009. Since the crisis was an external shock, the countries that were more open to trade and grew faster before the crisis experienced larger growth falls in 2009. Correspondingly, they are expected to recover the fastest, alongside the multispeed global revival (Figure A.I.5, Annex I). Nevertheless, as the global recovery remains fragile, there are downside risks to Africa's outlook.

Regarding other key macroeconomic indicators, the curtailed demand in the advanced economies and lower commodity prices led to a marked deterioration of trade and current account balances; oil exporters took a particularly heavy hit. A number of countries experienced 'twin deficits', as worsening current account balances were accompanied by rising fiscal deficits; no marked reversal occurred in 2010 except for oil exporters. In low income countries in general and (resource poor) fragile states in particular, the deterioration of the current account balances to high levels raises concerns about maintaining hard-won debt sustainability over the medium term (Table A.I.1, Annex I). Unemployment and working poverty have also escalated due to the crisis. ILO (2010) estimated that the working poverty (people living on less than 1.25 dollar a day) may have increased up to 15 percent in 2009 due to the crisis, which would bring the rates back to 2003 levels. Unemployment in Africa is also estimated to have increased markedly, by about $1-4$ million people between 2008 and $2009 .^{17}$

\section{Focus on private capital flows}

Given the importance of private capital flows in 'financing' Africa's economies, we discuss in some detail their developments during the global financial and economies crisis. On the eve of the global financial crisis, most of African economies had only limited links with the global financial system. Nevertheless, the substantial inflows in 2000 s made some emerging and

\footnotetext{
16 Parts of this section draw on African Development Bank, UNECA, AUC (2010), 'Africa's Voice on Development', presented at the 2010 KOAFEC Conference (Seoul, September).

17 Specific examples include the mining sector in Zambia where 28 percent of jobs were lost already in 2008 , while the manufacturing sector in South Africa shrank by about 20 percent in 2009.
} 
frontier market economies more integrated into the global financial markets, and more vulnerable to the risks of "sudden stops" and reversals of capital flows. ${ }^{18}$

- South Africa experienced "sudden stops" in 2008, when its external equity and bond issuance declined from about $\$ 20$ billion in 2007 to less than $\$ 4$ billion. Its stock market index plummeted in the last quarter of 2008 due to the net outflows and large equity price corrections, but has been gradually recovering since the second quarter of 2009.

-

- In contrast, capital flight from Nigeria led to a plummeting stock market index by 70 percent between February 2008 and March 2009; the market is yet to recover from these shocks. These developments amplified the difficulties of the banking sector, which stemmed mostly from poor governance and excessive lending to the energy sector. ${ }^{19}$

On balance though, due to low financial depth and under-developed financial systems in the low income and fragile countries which account for the bulk of Africa, the continent's overall financial integration is limited. Moreover, since most of the private capital flows to Africa took the form of FDI, the continent's exposure to the global credit crunch was less severe. ${ }^{20}$ Africa was thus mostly shielded from the direct impact through the financial channel when the crisis hit. Moreover, in a number of cases the vulnerability to external financial shocks has been reduced due to reforms that strengthened the financial sector and macro-prudential indicators, and debt relief received prior to the crisis. ${ }^{21}$ The policy space to absorb the massive external shock created by the crisis has thus been larger than prior to the previous crises.

SSA in particular has been more immune to the impact of the financial crisis than other developing and emerging market regions (Figure 4). ${ }^{22}$ While FDI flows to Africa continue to be small in absolute amounts, when measured in terms of GDP, in 2009 SSA received more net FDI inflows than emerging and developing countries on average. However, when it comes to official capital inflows to mitigate the crisis, SSA has received smaller amounts (even relative to GDP) than other developing regions except Asia, which has led the global recovery. ${ }^{23}$ The limited

18 In fact, according to investment-based indicators their degree of financial integration was close to that of emerging market countries in other regions, such as Latin America, albeit below that of the emerging Europe.

${ }^{19}$ In August 2009 the Central Bank of Nigeria injected funds equivalent to 2.5 percent of GDP into the banking system to raise the capital adequacy of the banks to the regulatory minimum level, when five leading Nigerian banks posted losses from non-performing loans. The management of the banks was replaced.

${ }^{20}$ Tong and Wei (2009) showed that the degree of credit crunch experienced by the emerging market and developing countries depended in part on the composition of their capital flows. Specifically, countries that were more exposed to the non-FDI private flows prior to the crisis also faced more severe credit crunch. For African low-income countries, the global credit crunch took mostly the form of limited trade financing.

${ }^{21}$ The banking sectors in Africa remain relatively profitable, partly due to restrictions on competition.

${ }^{22}$ For example, in 2008 SSA's non-FDI private financial inflows declined by only about 1 percentage point of GDP from the average of 2003-07, while those to the CIS declined by more than 9 percentage points on average.

${ }^{23}$ The regions hit the most severely by the crisis in 2009 - the emerging Europe and the CIS - also benefited the most from the assistance from the international community. 
availability of the official aid has also underscored the importance for African countries to attract adequate private capital flows to fuel growth, while managing their volatility.

\section{Counter-cyclical policies}

Due to the prudent macroeconomic stance and the debt relief prior to the crisis, a number of countries have built up sufficient policy space to adopt counter-cyclical measures when the crisis hit. Fiscal policies played a key role, for the most part through increased government expenditures on infrastructure (e.g., Kenya, Uganda, Tanzania). This policy choice is consistent with the need not only to stimulate short run aggregate demand through higher outlays, but also to release supply side bottlenecks over the medium term, thus laying the foundations for high growth. ${ }^{24}$ While countries also adopted an accommodative monetary stance, given the structural rigidities and limited links between interest rates and credit, monetary policy was much less effective in stimulating growth except in a few middle income countries (e.g., South Africa). Even frontier markets in East Africa had to rely more on fiscal policy to counter the crisis, with monetary policy being less effective (Figure A.I. 6).

Figure 4. Capital flows before and during the crisis, 2003-07, 2008 and 2009 1/

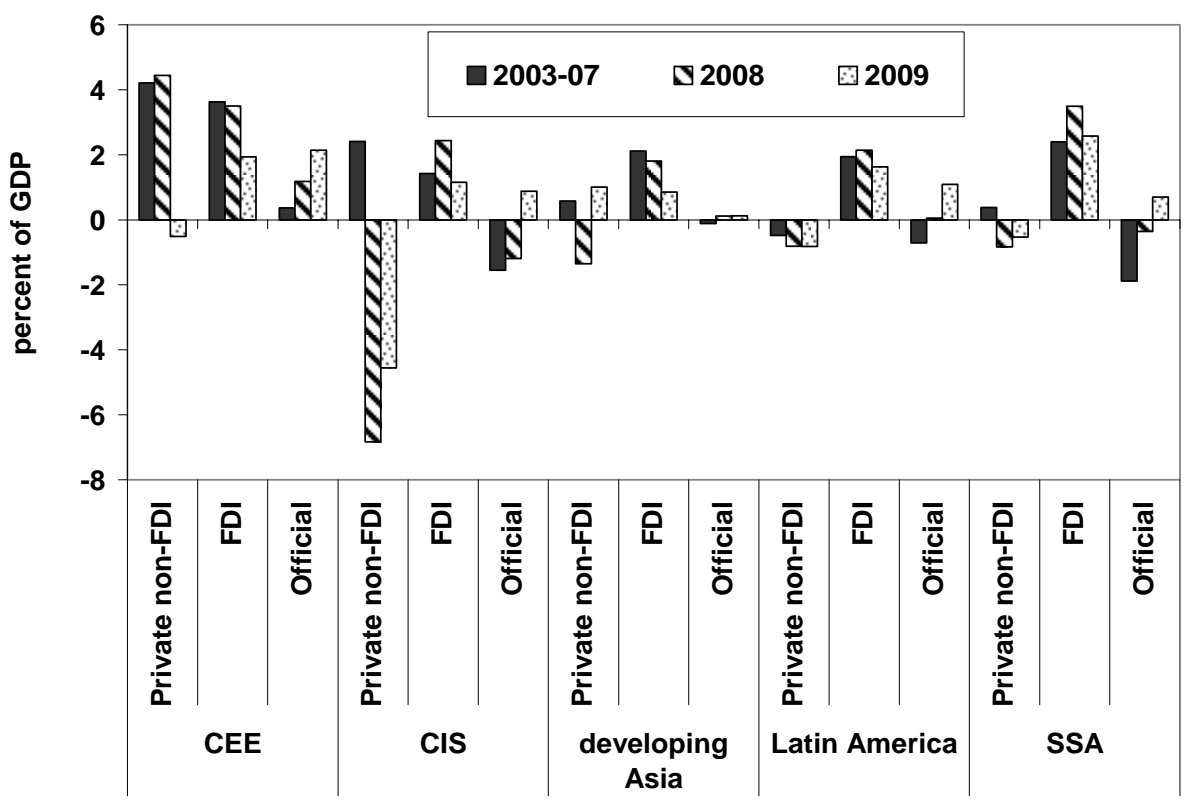

Source: Authors' calculations based on the IMF WEO database. 1/CEE denotes Central and Easter Europe and CIS stands for the Commonwealth of Independent States.

The crisis has thus also shown that in Africa cuts in policy rates do not necessarily increase credit to the private sector, pointing to structural rigidities and inefficiencies in financial systems. With these impediments, the private sector alone will not be able to drive Africa's nearterm recovery; continued effective state interventions will be needed.

\footnotetext{
${ }^{24}$ In Kenya, the government financed infrastructure by issuing local-currency infrastructure bonds. Kasekende, Brixiova and Ndikumana (2010) discuss the counter-cyclical policies of African countries during the crisis in detail.
} 


\section{Africa's near term prospects}

On balance though, Africa has shown a surprising resilience during this crisis and is now staging a robust comeback. The continent as a whole avoided recession, and output in only 10 out of 53 countries contracted in 2009. The growth is expected to reach 4.5 percent in 2010 and 5.2 in 2011. Except for Madagascar, all African countries are projected to record positive growth in 2010 and in 2011. Many, including some fragile states, are recovering fast as commodity prices rebound. According to the African Development Bank's projections, in 2011 Africa will be again one of the fastest growing world regions (Figure 5). At the same time, the multispeed global recovery still poses downside risks to Africa's outlook, while the potential growth could be permanently hampered by the crisis (Brixiova, Kamara and Ndikumana, 2010a).

Figure 5. Africa and other regions, real GDP growth (2006 - 2011, forecasted), percent

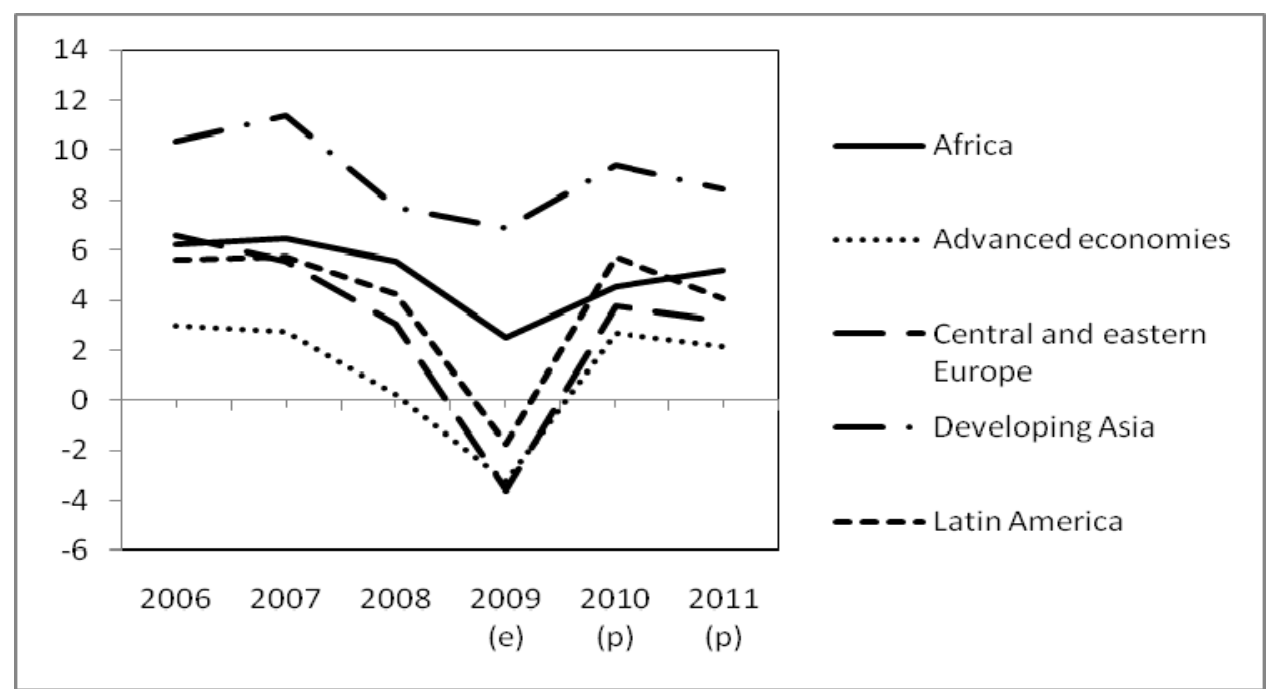

Sources: African Development Bank database and IMF WEO (October 2010).

Nevertheless, the impact was varied. In some countries (e.g., Swaziland, Cape Verde) the crisis has reduced the fiscal policy space by raising the deficit and financing it through debt. In others (e.g., Ghana, DRC) inflation accelerated, cutting the room for policies to stimulate aggregate demand. Finally, in spite of overall sound levels, in some countries (e.g., Chad, Malawi) international reserves declined markedly. For example, Chad's reserves collapsed by almost 50 percent between 2008 and 2009, from 3.8 months of imports to about 2 months. Similarly, Malawi's international reserves declined by 35 percent and stood at mere 2 weeks of imports in 2009 (down from 1 month in 2008).

Overall, Africa has weathered the crisis overall well due in part to: (i) cautious macroeconomic policies adopted across many countries prior to the crisis; (ii) appropriate counter-cyclical measures adopted where feasible; (iii) increased trade and investment linkages with Asia (e.g. Angola, Namibia, Gabon, Benin) and other emerging market countries; and (iv) in some sub-regions, more intensive regional integration and good diversification also helped. 


\section{Exit strategies from crisis interventions}

Despite the positive outlook, uncertainties stemming from a fragile global outlook surround also Africa's recovery. Given that in 2010 (and even 2011) many countries are projected to grow below their trend growth, the key policy challenge is to bring them on a path of strong, sustained and shared growth, including through demand management policies as a response to the crisis. In 2010, this suggestion is in line with the adopted policies -- about 40 percent of countries are projected to have higher fiscal deficit in 2010 than in 2009 (AfDB and OECD, 2010). African governments may want to maintain somewhat accommodative policies also in 2011, while gradually refocusing on medium term objectives and fiscal consolidation. Exit strategies from the crisis intervention policies should thus be gradual and well coordinated across countries and policies. ${ }^{25}$

Given the case for gradual exits from accommodative policies, the key question is then how much policy space, especially on the fiscal and inflation sides, African countries have to pursue accommodative stances in 2011. Despite a deterioration in a number of countries (Figure A.I.7, Annex I), most African countries have emerged from the crisis with stronger fiscal positions than the advanced economies. The countries hit particularly hard in 2009 were oil or mineral exporters which are expected to rebound quickly. A few exceptions aside, debt sustainability has not been so far a major concern, even though the problem may arise over the medium term unless the current stance is reversed. Often, the countries underperforming on growth (i.e. growing below their trend growth rates) are over-performing on inflation (i.e. with inflation rates either below 5 percent or within 5-10 percent, but below their trends) (Figure 6). In these cases, countries should not avoid stimulating aggregate demand out of fear of raising slightly inflation; bringing their economies on a high growth path is a much more urgent priority.

In sum, growth should be the key macro priority in the near term for most African countries, especially LICs. For those with 'room to inflate', inflation is not a priority right now as moderate increase can be reversed later, once high growth is restored. Still, with deteriorating fiscal and current account deficits, fiscal policy needs to ensure that any 'extra' public expenditures are growth oriented; increasing infrastructure spending can be particularly useful for removing supply-side bottlenecks. At the same time, African policy makers need to ensure that important social outlays remain protected or even scaled up. Building social safety nets is also important so that in the future the most vulnerable segments of the population are protected and growth is shared. A positive effect of such measures would be also the creation of automatic fiscal stabilizers on the expenditure side, now missing in most African countries.

\section{Beyond the crisis: pro-growth macroeconomic policies}

With Africa rebounding, the objectives of macroeconomic policy need to gradually shift from short-run stabilization policies geared at recovery to stimulating medium-term growth with job creation. ${ }^{26}$ Going forward, rather than overemphasizing price stability, macroeconomic

\footnotetext{
${ }^{25}$ Brixiova, Kamara, and Ndikumana (2010b) discuss the exit options for African countries in greater detail.

${ }^{26}$ In particular, going forward policy priorities should not overemphasize very low inflation at the cost of growth, as was typically the case before the crisis, particularly in low-income countries.
} 
policy should aim at supporting strong, sustained and shared growth as a way to build prosperity and reduce poverty in Africa's LICs.

As the crisis demonstrated, countries that had more flexible macroeconomic frameworks and built up cushions, especially through fiscal policy space, fared better. The main lesson from the crisis is that macroeconomic frameworks need to be more flexible while maintaining their credibility. On the fiscal side, LICs would benefit from replacing pro-cyclical policies of the past (Annex III) with rule-based and counter-cyclical frameworks that still leave room for discretion to counter unexpected shocks. In practical terms this means building automatic stabilizers on the expenditure side (e.g., social safety nets), while strengthening medium-term expenditure frameworks.

Figure 6. Africa: room to grow and room to inflate, 2010 1/

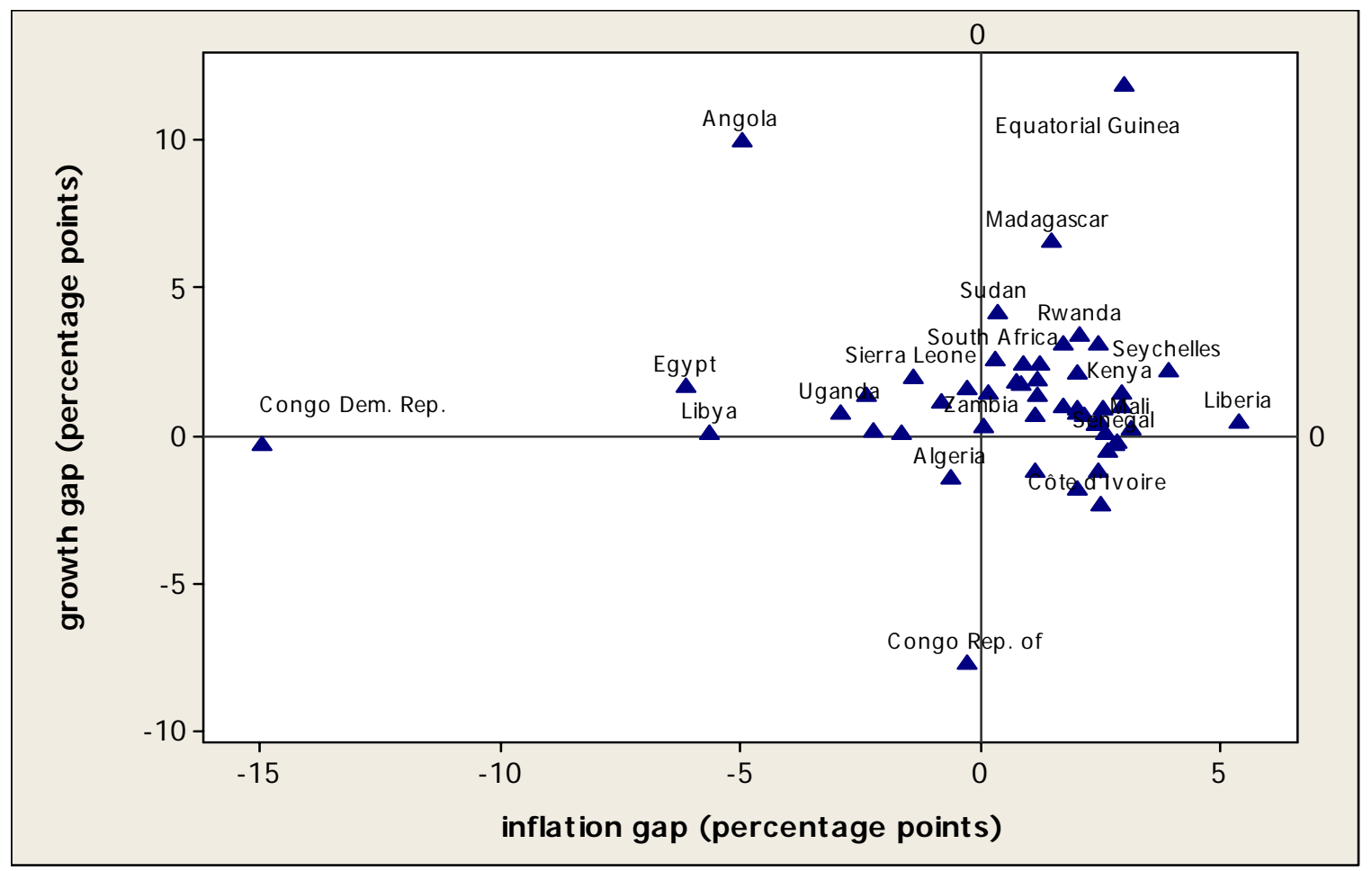

Source: Authors' calculations based on the AfDB database. 1/ Growth gap is the difference between the potential growth (average of 2006 - 2008) and the actual growth in 2010. Inflation gap is calculated as the difference between the targeted/trend inflation (average of 2001-2008) and the actual inflation in 2010. In cases where inflation trend was below 5 percent, target was set as 5. Similarly, where inflation trend was above 10 percent, target was set at 10 . Positive growth gaps mean that countries should aim at higher growth; positive inflation gap means that there may be some room to inflate, especially for low income countries with inflation below 5 percent.

In pro-growth oriented macroeconomic policy, phasing out pro-cyclical fiscal policies that prevailed in the run up to the crisis would in particular help achieve sustained growth by reducing output volatility. ${ }^{27}$ The objective of fiscal policy should thus be balancing budgets (net domestic financing) over the cycle. Given the need to raise efficiency of public spending and

${ }^{27}$ Evidence of procyclical patterns of fiscal policies is in Annex III. 
maintain debt sustainability, annual budgets should be anchored in medium-term expenditure frameworks. Such frameworks can also play a counter-cyclical role. Donors could support such frameworks by giving adequate official aid in a timely and predictable manner. Moreover, to avoid pro-cyclical fiscal cuts in downturns, African governments need to develop domestic debt markets and improve their access to debt financing, as the example of Kenya showed. For frontier market LICs, gaining access to international bond markets on more competitive terms is also important.

To reach strong, sustained and shared growth, public expenditures (and official aid) need to scale up public investments, whose share in budgets has been declining, in exchange for increasing social outlays. Given the limited domestic resources in a number of Africa's LICs (especially oil importers), the increased deficits will need to rely on either official aid or external private financing (e.g., Ghana) or local-currency infrastructure bonds (e.g., Kenya). Moreover, it will be important that African policy makers use the external sources in such a way that they stimulate domestic resource mobilization. While high tax levies surely discourage private investment and entrepreneurship, dynamic benefits of public expenditures for growth and development need to be taken into account and an optimal balance found (UNCTAD, 2010).

As the pre-crisis and crisis experience illustrated, monetary policy is not a particularly effective tool of macroeconomic management in Africa's LICs. As the globalized economy requires quick responses to shocks, there has been a world-wide trend towards more flexibility in monetary and exchange rate regimes, which is likely to continue and should be supported. ${ }^{28}$ Where conditions allow (in some frontier market LICs), consideration could thus be given to introducing flexible inflation targeting (IT) frameworks, as was done in South Africa and Ghana.

Recent global developments also showed once again the negative effects that freezing up of credit can have on growth. As the view that in developing countries monetary policy affects output mostly through the credit channel has gained acceptance, African central bankers have increasingly focused on credit as the key part of the monetary transmission mechanism. Hence going forward, a key task of monetary policy in Africa's LICs would be to ensure that sufficient private sector credit is available to fuel private investment and growth. ${ }^{29}$ At the same time, the role of public investment (especially in infrastructure) as a driver of growth is key, both through releasing supply side bottlenecks and through 'crowding in' private investment.

\section{Conclusions}

This paper reviewed macroeconomic policies in Africa prior to the crisis, with a special focus on LICs. It pointed out that while many countries, including many LICs, achieved very low inflation (below 5 percent a year) and higher growth than in the past, their growth was still not high enough to meaningfully reduce poverty and begin bridging the gap in living standards with

\footnotetext{
${ }^{28}$ In 1970s, 90 percent of all countries had fixed exchange rate regimes; in 2000 less than 30 percent of countries. In Africa, the share of countries with flexible regimes has also increased over time. According to the IMF classification, 44 countries out of 192 practiced formal inflation targeting as of April 31, 2008, up from 19 countries (among 187) that had this regime in 2003. Some countries target inflation informally.

${ }^{29}$ Such monetary policy needs to be accompanied by structural reforms to remove obstacles to obtaining credit, to be effective. Many other policies, including industrial policy to stimulate the private sector, policies geared towards regional integration and product diversification as well as building of social safety nets, are key for strong and shared growth. They are outside of the scope of this paper and are covered elsewhere (AfDB, UNECA, AUC, 2010).
} 
advanced economies. At the same time, the cushions built up prior to the crisis as well as increased trade and investment relations with emerging markets helped Africa weather the external shock and stage a relatively fast recovery.

The paper underscores that in the aftermath of the crisis, the emphasis of macroeconomic policy needs to shift from the objective of stabilization and achieving low inflation that predominated prior to the crisis towards supporting strong, sustained and shared growth. To reach this goal, countries would benefit from macroeconomic frameworks (i.e. fiscal, monetary and exchange rate regimes) that are more flexible, while maintaining credibility. Fiscal policy is key in this regard, through public outlays on infrastructure anchored in the medium term expenditure frameworks that also have a counter-cyclical role. Where conditions allow, frontier market LICs may want to consider adopting flexible inflation targeting frameworks that provide sufficient room for providing credit to the private sector. To be effective, efforts in the area of macroeconomic policy would need to be accompanied by structural reforms to address supply side bottlenecks. To achieve shared growth, African policymaker will need to put even greater emphasis on creation of highly productive jobs and building up of formal social safety nets, which are still vastly missing in Africa. 


\section{ANNEX I - TABLES AND FIGURES}

Table AI.1a. Selected Macroeconomic Indicators Prior, During and After the Last 2 Crises 1/

\begin{tabular}{|c|c|c|c|c|c|c|c|c|}
\hline & 1986-90 & 1991 & 1992 & 1993 & 2004-08 & 2009 & 2010 & 2011 \\
\hline \multicolumn{9}{|c|}{ (\% of GDP, unless otherwise indicated) } \\
\hline & & & & & & & & \\
\hline & \multicolumn{8}{|c|}{ Oil Exporting Countries } \\
\hline Real GDP growth (\%) & 1.5 & 0.8 & 0.0 & -2.8 & 6.9 & 2.4 & 4.9 & 4.9 \\
\hline Inflation $(\%)$ & 9.6 & 19.1 & 19.3 & 18.8 & 6.8 & 10.3 & 7.7 & 6.4 \\
\hline Current account balance & -6.0 & -4.9 & -5.5 & -5.5 & 6.1 & -4.1 & 1.9 & 2.9 \\
\hline \multirow[t]{3}{*}{ Fiscal balance } & -6.0 & -2.4 & -3.0 & -5.2 & 3.6 & -0.5 & 2.3 & 2.1 \\
\hline & & & & & & & & \\
\hline & \multicolumn{8}{|c|}{ Emerging Market Countries } \\
\hline Real GDP growth (\%) & 5.9 & 4.2 & 3.6 & 2.7 & 4.9 & 0.1 & 3.6 & 4.1 \\
\hline Inflation $(\%)$ & 9.1 & 8.9 & 7.7 & 9.1 & 5.9 & 7.7 & 4.5 & 4.5 \\
\hline Current account balance & 0.5 & 0.5 & -1.2 & -2.3 & -2.9 & -7.1 & -8.1 & -8.2 \\
\hline \multirow[t]{3}{*}{ Fiscal balance } & -3.2 & -2.6 & -5.5 & -6.8 & -1.9 & -5.7 & -4.6 & -4.9 \\
\hline & & & & & & & & \\
\hline & \multicolumn{8}{|c|}{ Low Income Countries, Frontier markets } \\
\hline Real GDP growth (\%) & 4.9 & 0.3 & -0.3 & 4.2 & 6.3 & 4.7 & 5.5 & 6.1 \\
\hline Inflation $(\%)$ & 49.5 & 31.5 & 46.4 & 46.7 & 9.7 & 9.6 & 8.3 & 6.7 \\
\hline Current account balance & -5.8 & -5.8 & -5.8 & -7.3 & -6.9 & -10.4 & -10.6 & -9.4 \\
\hline \multirow[t]{3}{*}{ Fiscal balance } & -5.7 & -3.9 & -4.2 & -4.6 & 0.9 & -3.5 & -4.1 & -3.8 \\
\hline & & & & & & & & \\
\hline & \multicolumn{8}{|c|}{ Low Income Countries, Transition } \\
\hline Real GDP growth (\%) & 2.6 & 1.0 & -0.6 & 2.5 & 6.4 & 4.9 & 5.2 & 6.0 \\
\hline Inflation (\%) & 10.3 & 16.3 & 13.8 & 12.5 & 10.2 & 11.7 & 6.4 & 6.2 \\
\hline Current account balance & -8.2 & -12.8 & -12.4 & -11.3 & -10.0 & -10.1 & -8.6 & -8.8 \\
\hline \multirow[t]{3}{*}{ Fiscal balance } & -7.0 & -7.0 & -7.7 & -5.8 & -0.6 & -0.1 & -1.6 & -3.4 \\
\hline & & & & & & & & \\
\hline & \multicolumn{8}{|c|}{ Low Income Countries, Pre-transition } \\
\hline Real GDP growth (\%) & 2.8 & 1.8 & 0.6 & 1.4 & 4.7 & 1.1 & 3.3 & 4.7 \\
\hline Inflation $(\%)$ & 6.1 & 4.1 & 4.7 & 3.3 & 6.0 & 4.0 & 4.3 & 4.1 \\
\hline Current account balance & -4.4 & -3.1 & -3.5 & -4.4 & -12.4 & -12.8 & -14.5 & -16.1 \\
\hline \multirow[t]{3}{*}{ Fiscal balance } & -10.8 & -13.7 & -14.3 & -12.3 & 5.6 & 3.1 & -2.0 & -2.3 \\
\hline & & & & & & & & \\
\hline & \multicolumn{8}{|c|}{ Low Income Countries, Fragile states } \\
\hline Real GDP growth (\%) & -0.2 & -2.1 & -5.3 & -4.1 & 3.9 & 2.6 & 4.1 & 4.8 \\
\hline Inflation (\%) & 29.4 & 28.0 & 23.4 & 13.3 & 9.8 & 5.5 & 5.5 & 4.7 \\
\hline Current account balance & -11.7 & -8.8 & -14.2 & -8.7 & -9.7 & -14.9 & -16.3 & -15.7 \\
\hline Fiscal balance & -5.6 & -14.6 & -7.6 & -6.3 & 2.0 & -0.6 & -2.6 & -3.2 \\
\hline
\end{tabular}

Source: Authors' calculations based on the African Development Bank database. 1/ Un-weighted averages. The country grouping is defined in Table AI.1b. 
Table A.I.1b. Country classification ${ }^{30}$

\section{Oil Exporters}

Angola

Cote d'Ivoire

Cameroon

Congo, Rep.

Algeria

Egypt

Gabon

Equatorial Guinea

Libya

Nigeria

Sudan

Chad

Congo, Dem. Rep.

\section{Emerging}

Markets

Botswana

Cape Verde

Mauritius

Morocco

Namibia

Seychelles

South Africa

Swaziland

Tunisia

\section{LICs, Frontier}

Markets

Ghana

Kenya

Mozambique

Senegal

Tanzania

Uganda

Zambia

LICs Fragile States

Burundi

Central African

Republic

Comoros

Guinea

Guinea Bissau

Liberia

Sierra Leone

\section{LICs, Transition}

Burkina Faso

Djibouti

Ethiopia

Lesotho

Malawi

Rwanda

Sao Tome and

Principe

\section{LICs, Pre-transition}

Benin

Gambia

Madagascar

Mali

Mauritania

Niger

Togo

\footnotetext{
${ }^{30}$ Besides oil resources, the main distinguishing criteria for this grouping are (i) income level (GDP per capita); growth trends and prospects (e.g. private sector development) and (ii) the level of development of financial markets, including access to international capital markets.
} 
Table AI.2. Africa and developing Asia: Savings, Investment and Net Capital Flows, 1991 $2008^{31}$

\begin{tabular}{|c|c|c|c|c|c|c|c|}
\hline & $1991-95$ & $1996-2000$ & 2001-05 & 2006-08 & 2006 & 2007 & 2008 \\
\hline & \multicolumn{7}{|c|}{$\%$ of GDP } \\
\hline \multicolumn{8}{|l|}{ Investment } \\
\hline Africa & 19.4 & 19.4 & 21.8 & 23.6 & 21.8 & 23.9 & 25.1 \\
\hline North Africa & 23.4 & 21.1 & 26.5 & 27.6 & 25.2 & 28.0 & 29.4 \\
\hline Sub-Saharan Africa & 17.3 & 18.3 & 19.0 & 21.5 & 20.2 & 21.7 & 22.7 \\
\hline Developing Asia & 33.9 & 31.6 & 33.6 & 37.9 & 37.9 & 37.8 & 38.1 \\
\hline \multicolumn{8}{|l|}{ Saving rates $1 /$} \\
\hline Africa & 18.0 & 18.8 & 22.8 & 28.2 & 28.1 & 27.6 & 28.9 \\
\hline North Africa & 24.2 & 23.4 & 33.5 & 40.4 & 40.6 & 40.5 & 40.0 \\
\hline Sub-Saharan Africa & 14.6 & 15.8 & 16.7 & 21.8 & 21.8 & 20.9 & 22.7 \\
\hline Developing Asia & 31.9 & 32.5 & 36.2 & 44.2 & 44.0 & 44.9 & 43.8 \\
\hline \multicolumn{8}{|l|}{$C A B / G D P 2 /$} \\
\hline Africa & -1.5 & -0.6 & 1.1 & 4.6 & 6.3 & 3.8 & 3.8 \\
\hline North Africa & 0.8 & 2.3 & 7.0 & 12.8 & 15.4 & 12.4 & 10.6 \\
\hline Sub-Saharan Africa & -2.7 & -2.6 & -2.3 & 0.3 & 1.7 & -0.8 & -0.1 \\
\hline Developing Asia & -2.0 & 1.0 & 2.7 & 6.3 & 6.1 & 7.1 & 5.7 \\
\hline \multicolumn{8}{|l|}{$\Delta R$ (reserves) 3/ } \\
\hline Africa & -0.7 & -0.6 & -2.6 & -4.2 & -5.0 & -4.2 & -3.4 \\
\hline North Africa & -1.4 & -1.0 & -4.8 & -8.5 & -8.9 & -9.0 & -7.7 \\
\hline Sub-Saharan Africa & -0.4 & -0.4 & -1.2 & -2.0 & -2.9 & -1.8 & -1.2 \\
\hline Developing Asia & -1.9 & -1.2 & -5.1 & -7.8 & -6.8 & -10.7 & -6.0 \\
\hline \multicolumn{8}{|l|}{ Net capital flows - total } \\
\hline Africa & 2.2 & 1.2 & 1.5 & 1.4 & -1.3 & 0.4 & -0.4 \\
\hline North Africa & 0.6 & -1.3 & -2.2 & -4.3 & -6.5 & -3.5 & -3.0 \\
\hline Sub-Saharan Africa & 3.1 & 2.9 & 3.6 & 1.7 & 1.3 & 2.6 & 1.2 \\
\hline Developing Asia & 4.0 & 0.3 & 2.4 & 1.5 & 0.7 & 3.6 & 0.3 \\
\hline \multicolumn{8}{|l|}{ Memorandum items } \\
\hline \multicolumn{8}{|l|}{ Private capital flows } \\
\hline North Africa & 1.3 & 1.1 & 1.1 & 2.4 & 1.1 & 2.5 & 3.6 \\
\hline Sub-Saharan Africa & 1.0 & 2.0 & 1.9 & 2.9 & 2.5 & 3.1 & 3.2 \\
\hline
\end{tabular}

Source: Authors' calculations based on the African Development Bank database, the IMF WEO database for Asia, and authors' calculations. 1/ National savings rates. 2/ Includes errors and omissions. 3/ Increase in foreign reserves is recorded as negative $\Delta R$.

${ }^{31}$ Developing Asia is defined as in the IMF's 2010 World Economic Outlook. 
Figure AI.1.a. Inflation and growth in Africa's LICs, 1990-1999

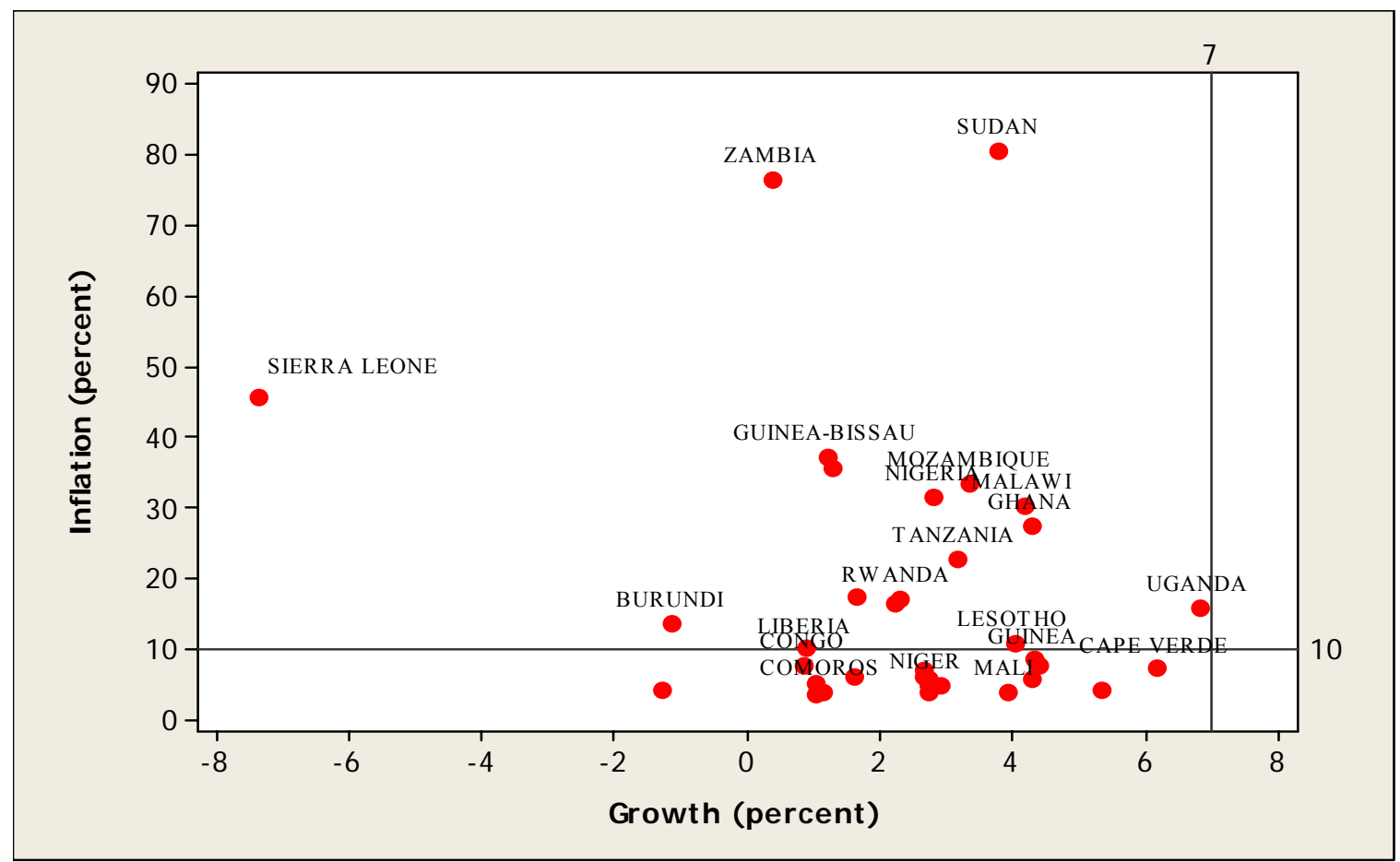

Figure AI.1.b. Inflation and growth in Africa's LICs, 2000 - 2008

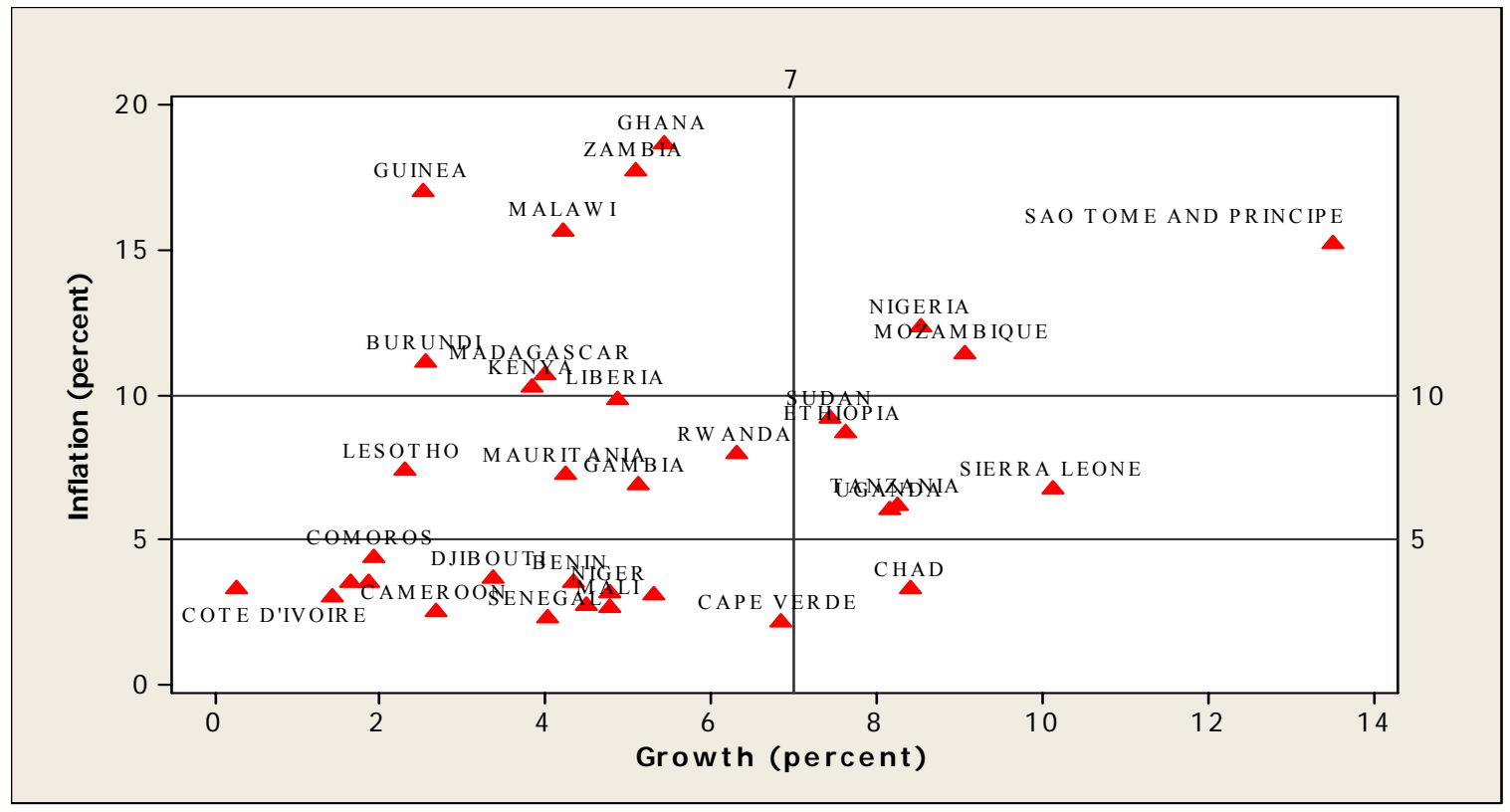

Source: African Economic Outlook and authors' calculations. 
Figure AI.2.a. Africa's frontier markets: average and standard deviation of inflation



Figure AI.2.b. Africa's transition countries and fragile states: average and standard deviation of inflation

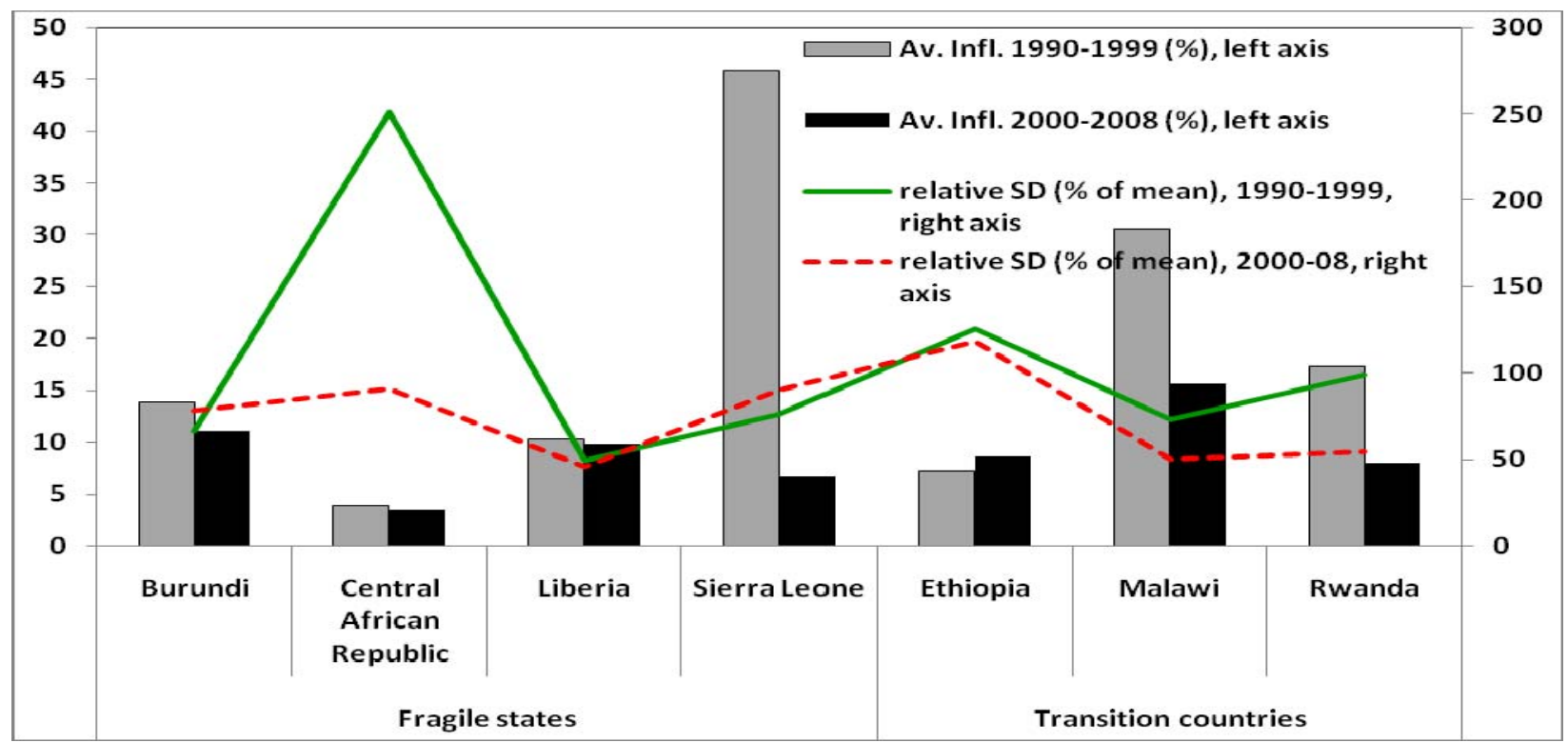

Sources: Authors' calculations based on African Development Bank database. 
Figure AI.3.a. Foreign Exchange Reserves (stocks), 1991 - 2009 (\% of GDP)

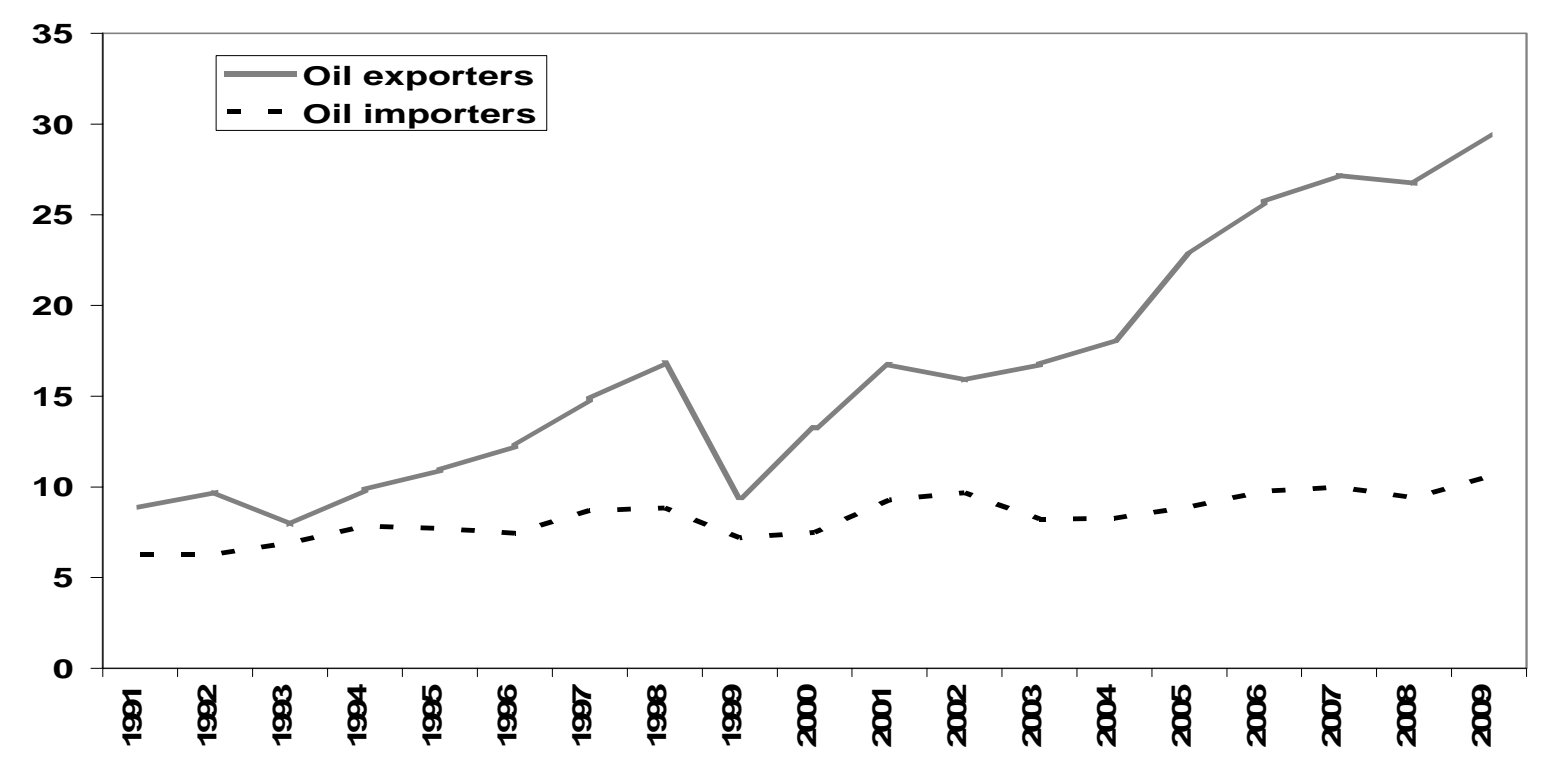

Source: African Economic Outlook database and authors' calculations.

Figure AI.3b. Growth of Real Credit to the Private Sector in SSA, 2003 - 2009 (\%)

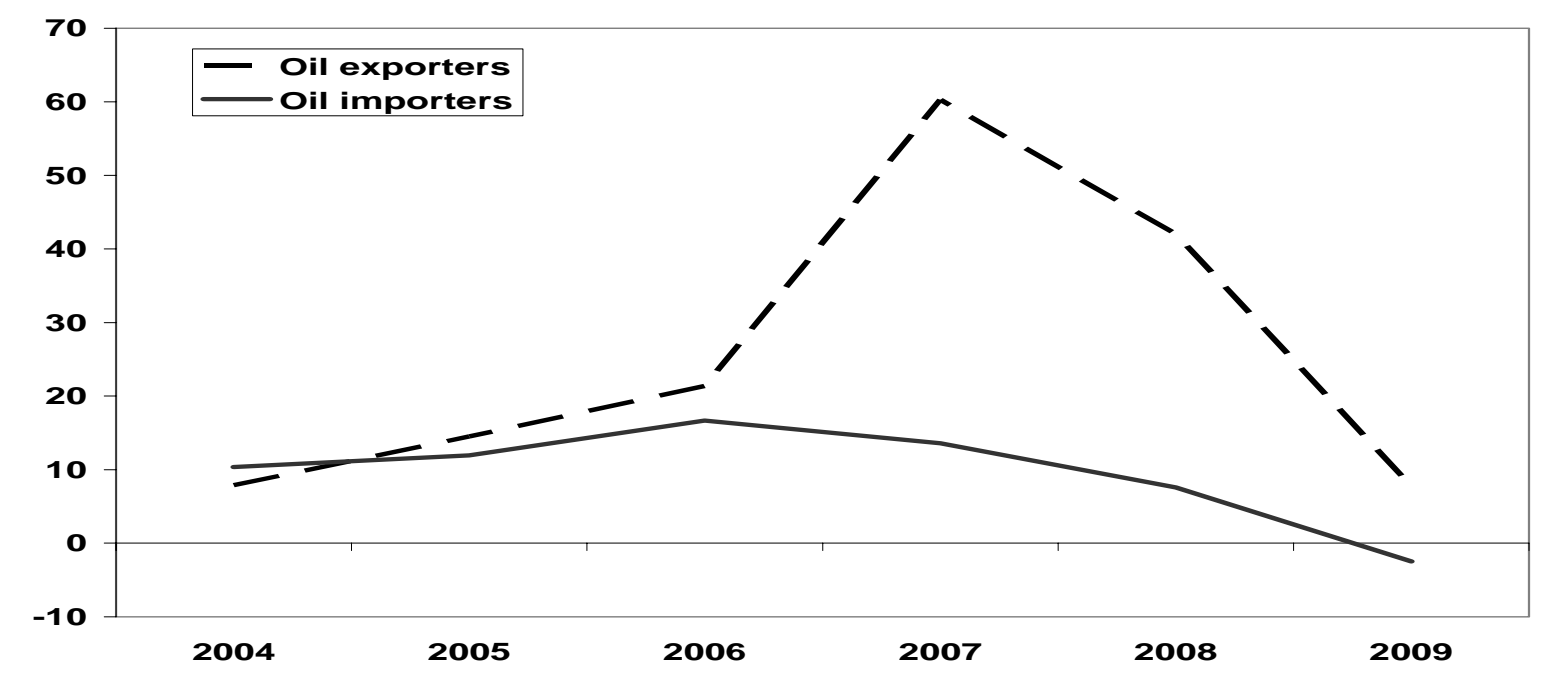

Source: IMF Regional Economic Outlook for sub-Saharan Africa (April 2010) and authors' calculations. 
Figure AI.4.a: South Africa: FDI Inward stock in 2006, by sector (\% of total)



Source: Investment map, UNCTAD \& ITC 2010.

Figure AI.4.b. Africa: FDI Inflows to Oil Exporters and Importers, 1990-2008 (million of US\$)

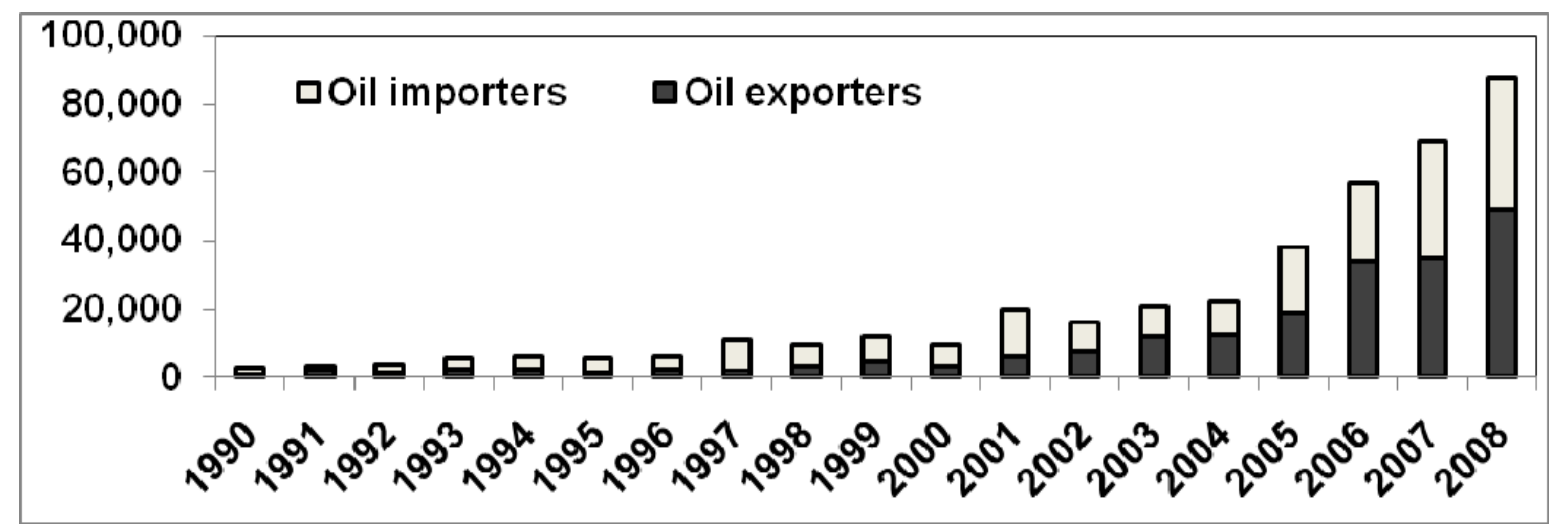

Source: Authors' calculations based on UNCTAD (2009a).

Figure AI.4.c. South Africa's Outward FDI in the Rest of Africa, 2001 - 2008, Millions of Rand 1/

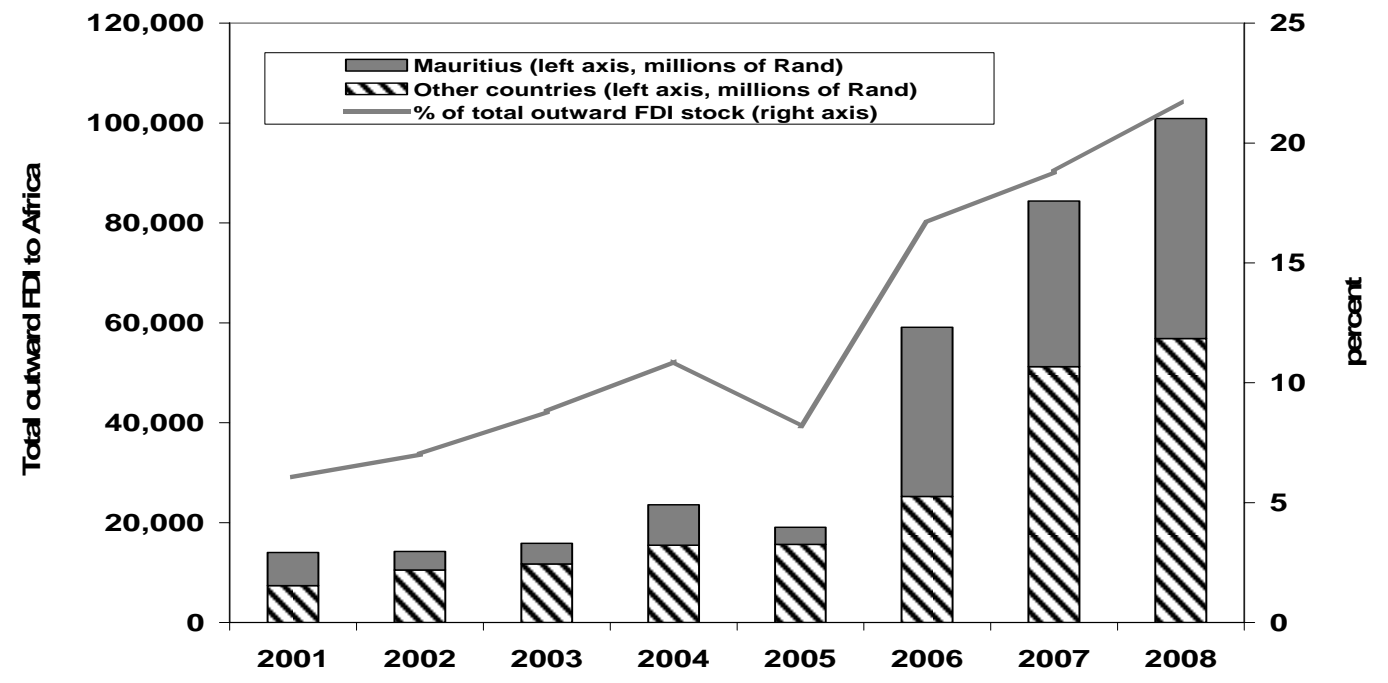

Source: Authors' calculations based on Reserve Bank of South Africa data. 1/ Stock as of December 31. 
Figure AI.5.a. Fastest growing countries in 2008 declined the most in 2009 1/



Source: African Economic Outlook and authors' calculations. 1/ Correlation coefficient -0.489 at 1 percent significance level.

Figure A.I.5.b. Least growing countries in 2009 rebounded the most in 2010 1/



Source: African Economic Outlook database and authors' calculations. 1/ Correlation coefficient -0.762 at 1 percent significance level. 
Figure A.6.a. Policy rates and growth of credit to the private sector in Tanzania, $2003-10$ (\%)



Figure A.6.b. Policy rates and growth of credit to the private sector in Uganda, 2003 - 10 (\%)

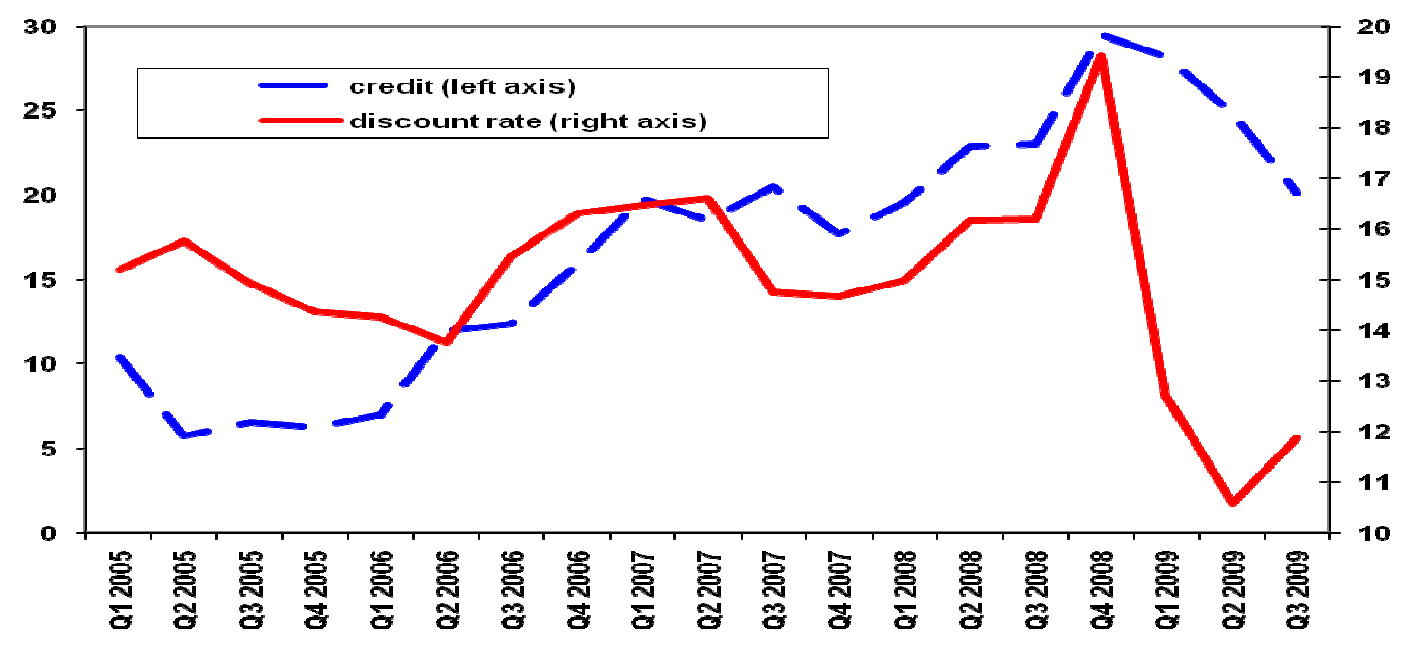

Source: Authors' calculations based on the African Development Bank database and Central Banks' websites. 


\section{ANNEX II - Impact of FDI on productivity in selected countries: an empirical investigation}

In this Annex we empirically investigate the FDI-productivity nexus in selected West African countries, using the growth accounting framework. In this framework, FDI affects growth and productivity through its effect on total factor productivity (TFP), which would result from technology transfer and knowledge diffusion, the increased efficiency in management, competition, and better production techniques. It also looks at the impact of capital on output (MPK). In the growth accounting approach, output is produced according to:

$$
Y=A L^{\alpha} K^{1-\alpha}
$$

where $Y$ is output, $A$ is TFP, $L$ is labor, $K$ is capital, and $\alpha(1-\alpha)$ is the share of labor (capital) in output. The marginal product of capital becomes:

$$
M P K_{p}=(1-\alpha) A L^{\alpha} K^{-\alpha},
$$

that is assuming identical technologies ( $\alpha$ and $A$ ), cross-country differences in marginal productivity of capital stem from differences in the level of capital. Countries with same levels of capital would differ in their rates of return on capital depending on the level of TFP, $A$.

Denoting FDI stock as $F$, the aggregate production function becomes:

$$
Y=A(F) L^{\alpha} K^{1-\alpha}
$$

with $A(F)$ reflecting the possibility that FDI influences TFP. Marginal product of FDI under this production function becomes:

$$
A_{F} L^{\alpha} K^{1-\alpha}+(1-\alpha) A(F) L^{\alpha} K^{-\alpha}=A_{F} L^{\alpha} K^{1-\alpha}+M P K_{p},
$$

where $A_{F}$ is the effect of FDI on TFP. Where such spillover effect is positive, the 'social' return on FDI is higher than the private marginal product of capital, $(1-\alpha) A L^{\alpha} K^{-\alpha}$. The total differentiation of logarithm of (3) yields the following modified growth accounting equation:

$$
\frac{d Y}{Y}=\frac{A_{F} d F}{A}+\alpha \frac{d L}{L}+(1-\alpha) \frac{d K}{K}
$$

Since from (1), $(1-\alpha)=M P K_{p} \frac{K}{Y}$ and $d K=I$, the last term becomes $\beta \frac{I}{Y}$, where $\beta=M P K_{p}$. Similarly, the first term of (5) can be rewritten as $A_{F} \frac{Y}{A} \frac{d F}{Y}$ where $d F$ is FDI flow and $\lambda=A_{F} \frac{Y}{A}$ is the first term of (4). Denoting $\lambda$ to be the marginal product of TFP due to FDI spillovers, $A_{F} L^{\alpha} K^{1-\alpha}$, equation (5) then takes the following form:

$$
\frac{d Y}{Y}=\lambda \frac{d F}{Y}+\alpha \frac{d L}{L}+\beta \frac{I}{Y}
$$

Annual time-series data for emerging and frontier markets in West Africa (Cape Verde, Ghana, Nigeria, and Senegal) in 1987 - 2008 are used and results compared with those for Egypt. The data for FDI, GDP (in 2000 constant prices), and investment (in 2000 constant prices) in these countries were obtained from the African Development database. The employment data are taken from the ILO database. The ordinary least squares (OLS) method is 
used to estimate the relationship between FDI and economic growth (Table AII.1). Estimations were carried out with Minitab (version 15) and Stata (version 10).

Table AII.1 presents several insights about the impact of FDI on growth and channels of transmission in these countries. ${ }^{32}$ Specifically, regarding the impact of FDI on growth through positive spillovers (TFP), Table AII.1 shows that among the four West African countries studied (Cape Verde, Ghana, Senegal, and Nigeria), $\lambda$ is positive and statistically significant only for Cape Verde and Egypt. It implies that a 1\% increase in FDI investment increases the Cape Verde's growth rate by about $0.31 \%$ and Egypt's growth by $0.4 \%$, through increasing TFP. In Senegal and Ghana, the positive impact on FDI occurs through the increased the marginal product of capital. In Nigeria, FDI does not have any significant impact at the aggregate level.

Table AII.1. Regression Results (Dependent Variable: Growth Rate of Real GDP)

\begin{tabular}{lcccc}
\hline & I/GDP & FDI/GDP & $\Delta \mathrm{L} / \mathrm{L}$ & Adjusted $\mathrm{R}^{2}$ \\
\hline Cape Verde & $0.0231(0.17)$ & $0.3048 *(1.99)$ & $-2.553(-0.99)$ & 0.052 \\
Ghana & $0.0869 *(2.29)$ & $-0.1292(-0.77)$ & $-0.0230(-0.12)$ & 0.157 \\
Nigeria & $0.4671(1.48)$ & $-0.2458(-0.48)$ & $21.44(1.41)$ & 0.058 \\
Senegal 1/ & $0.1659 *(1.91)$ & $0.7736(1.67)$ & $-5.987(-1.45)$ & 0.318 \\
Sierra Leone & $0.0263(0.04)$ & $0.1599(0.33)$ & $4.697 *(3.06)$ & 0.295 \\
Egypt & $0.01162(0.16)$ & $0.4003 *(2.71)$ & $0.1862(0.67)$ & 0.212
\end{tabular}

Source: Authors' calculations. * Denotes significance at 5\%;** significance at 10\%. 1/ Data are for $1988-2008$.

As the next step, the aggregate incremental capital-output ratio (ICOR) and the social marginal product of capital are derived (Table AII.2). ${ }^{33}$ Comparing the private marginal product of capital (MPK) and the social marginal product of capital (SMPK) reveals that in all countries except Nigeria the social return on capital is above the private one, albeit slightly. Investment in Nigeria is thus more rewarding to the private investors than to the society at large. This can be in part explained by the fact that most investment in Nigeria goes to the oil sector, and hence positive externalities are more challenging to generate. This sector's influence on economic performance is constrained weak institutions and lack of capacity to maximize resource rents.

\footnotetext{
32 The growth accounting equation has a particularly limited explanatory power for variations of growth rates in Nigeria and Cape Verde. In Nigeria, the economic performance is large driven by fluctuations in oil prices, while Cape Verde is heavily dependent on remittances which accounted for about 20 percent of GDP in 2000s.

33 The social marginal product of capital captures the impact of all factors on the productivity of capital. In contrast, private marginal return to capital reflects only the impact of FDI.
} 
Table AII.2. ICOR and Marginal Product of Capital (MPK), average for 1987 - 2008

\begin{tabular}{llllll} 
& Cape Verde & Ghana & Nigeria & Senegal & Egypt \\
\hline ICOR & 7.34 & 4.98 & 2.64 & 4.72 & 8.2 \\
SMPK (soc.) & 0.14 & 0.20 & 0.38 & 0.21 & 0.12 \\
MPK (priv.) & 0.02 & 0.09 & 0.47 & 0.19 & 0.01 \\
Difference & 0.11 & 0.11 & -0.09 & 0.03 & 0.11 \\
\hline
\end{tabular}

Source: Authors' calculations based on the African Development Bank database. 


\section{ANNEX III -- FISCAL POLICY CYCLES IN AFRICA DURING 1980 - 2007}

\section{Methodology}

In this Annex, the cyclical properties of fiscal policy are evaluated through the comovement of the cyclical component of the real output (obtained through HP and/or band pass filters) and (i) real government consumption; (ii) real government revenues; (iii) real private consumption (as indication of tax base); (iii) inflation tax rates (as indication of tax rates).

Conceptually, the cyclical stance of fiscal policy is measured by policy instruments, rather than outcomes, as in Kaminsky, Reinhart, and Vegh (2004). One of the key instruments is government consumption (which excludes transfers and debt service outlays) on the expenditure side, and tax rates on the revenue side. ${ }^{34}$ However, since reliable information on tax rates in developing countries, including in Africa, is sparse, this note relies on inflation tax rate instead for measuring tax rates and on real private consumption for measuring the tax base.

The sample period is from 1980 to 2007 . The main sources used are the annual data from the African Development Bank and the IMF's World Economic Outlook databases.

\section{Results}

First the cyclical co-movement of the aggregate series for the entire Africa's real GDP and real government consumption during $1980-2007$ is examined (Table AIII.1). To ensure that the results are not affected by the increased capital inflows that Africa has experienced since mid-1990s, the sample is split into two sub-periods: (1980-1994 and 1995 - 2007). Expenditure polices were indeed pro-cyclical in both periods. However, differences emerge between subgroups, with SSA and oil importers having more pro-cyclical patterns of spending than the other groups (Table AIII.2).

Table AIII.1. Africa: Correlation between real government consumption and real GDP 1/

\begin{tabular}{lc} 
& HP filter \\
\hline Aggregate, $1980-\mathbf{2 0 0 7}$ & $\mathbf{0 . 4 4 3 ^ { * }}$ \\
Aggregate, $1980-1994$ & 0.366 \\
Aggregate, $1995-2007$ & $0.524^{*}$ \\
\hline
\end{tabular}

Source: Authors' calculations based on the AfDB database. 1/ Correlation between the cyclical component of real GDP and real government spending; through HP filter. * Denotes significance at $10 \%$.

To find out whether the actual revenue (tax) policies were procyclical, the revenues $(T R)$ need to be decomposed into tax rates $\tau$ and the tax base $(T B): T R=\tau . T B$. In that context, Table AIII.3 shows that the tax base, approximated by real private consumption, was also highly procyclical during $1980-2007$.

\footnotetext{
${ }^{34}$ Even though widely used, the fiscal deficit may not provide a clear indication of the cyclical stance of fiscal policy, because of the endogeneity of tax revenues. Structural balance, in turn, may contain temporary revenue increases due to asset price booms, privatization, official aid, etc.
} 
Table AIII.2. Correlation between real government consumption and GDP by sub-groups 1/

\begin{tabular}{lccc}
\hline & $1980-2007$ & $1980-1994$ & $1995-2007$ \\
\hline By regions & & & \\
North Africa & 0.116 & -0.104 & 0.310 \\
Sub-Saharan Africa & $0.437^{*}$ & 0.380 & $0.496^{*}$ \\
& & & \\
By resource endowments & & & \\
Net oil exporters & 0.264 & 0.138 & 0.379 \\
$\quad$ Net oil importers & $0.581^{*}$ & 0.316 & $0.809^{*}$ \\
frican Economic Outlook database and authors' calculations. 1/ Correlation between the cyclical \\
of real GDP and real government spending obtained through HP filter. * indicates significance at $10 \%$.
\end{tabular}

Table AIII.3. Africa: Correlation between real government revenues, private consumption and GDP 1/

\begin{tabular}{lccc}
\hline & $1980-2007$ & $1980-1994$ & $1995-2007$ \\
\hline Real government revenues & $0.700^{*}$ & $0.821^{*}$ & $0.623^{\star}$ \\
Private consumption & $0.723^{\star}$ & $0.864^{*}$ & $0.651^{*}$ \\
Inflation tax rate 2/ & -0.208 & -0.321 & -0.086 \\
\hline
\end{tabular}

Source: African Economic Outlook database and authors' calculations. $1 / *$ indicates significance at $10 \% .2 /$ Correlation between cyclical components. For inflation tax rates, a negative number indicates pro-cyclicality.

Moreover, cyclical behaviour of fiscal policy was asymmetric, as Africa's fiscal stance was more pro-cyclical in good than in bad times (Table AIII.4). Applying the political economy interpretation of Talvi and Vegh (2005), this suggests that political pressures to spend during good times are stronger than constraining factors in bad times. Exceptions to the observation of generally more procyclical policies in good than bad times are WAEMU and oil exporters.

Table AIII.4. Correlations of government consumption cycles in good and bad times

\begin{tabular}{|c|c|c|}
\hline & Good times & Bad times \\
\hline Africa & 0.342 & 0.174 \\
\hline \multicolumn{3}{|l|}{ By regions } \\
\hline North Africa & -0.148 & $0.517^{*}$ \\
\hline Sub-Saharan Africa & $0.706^{*}$ & -0.076 \\
\hline \multicolumn{3}{|l|}{ By regional agreements } \\
\hline EAC & 0.425 & $-0.429 *$ \\
\hline SADC & $0.758^{*}$ & -0.329 \\
\hline WAEMU & -0.014 & 0.112 \\
\hline WAMZ & 0.253 & -0.403 \\
\hline \multicolumn{3}{|c|}{ By resource endowments } \\
\hline Net oil exporters & -0.189 & 0.309 \\
\hline Net oil importers & $0.784^{*}$ & 0.002 \\
\hline
\end{tabular}

Source: African Economic Outlook database and authors' calculations. 1/ Correlation between the cyclical component of real GDP and real government spending obtained through HP filter. ${ }^{*}$ indicates significance at $10 \%$. 


\section{References}

African Development Bank, UNECA, AUC (2010), 'Africa's Voice on Development', Paper prepared for the 2010 KOAFEC Ministerial Conference (Seoul, September).

Aghion, P.; Comin, D.; Howitt, P. and Tecu, I. (2009), 'When Does Domestic Savings Matter for Economic Growth?' Harvard Business School Working Paper 08-090.

Alfaro, L. (2003), 'Foreign Direct Investment and Growth: Does the Sector Matter?' Harvard Business School: http://www.people.hbs.edu/lalfaro/fdisectorial.pdf (as of August 2010).

Borensztein, E.; De Gregorio, J. and Lee, J. W. (1998), 'How does Foreign Direct Investment Affect Economic Growth?', Journal of International Economics, Vol. 45(1), 115-135.

Brixiova, Z.; Kamara, A. and Ndikumana, L. (2010a): 'Containing the Impact of the Crisis and Paving the Way for a Strong Recovery in Africa' African Development Bank Policy Brief on the Financial Crisis No. 2/2010.

Brixiova, Z.; Kamara, A. and Ndikumana, L. (2010b): 'Africa Rebounding: When and How to Exit from Crisis Intervention Policies?' African Development Bank Policy Brief on the Financial Crisis No. 4/2010.

Collier, P. (2007), 'Africa's Economic Growth: Opportunities and Constraints', African Development Review, Vol. 19 (1), 6-25.

Devarajan, S. and Kasekende, L. (2009), 'Africa and the Global Economic Crisis: Impacts, Policy Responses and Political Economy', paper presented at the AERC Conference on Rethinking African Economic Policy in Light of the Global Economic and Financial Crisis (Kenya, November 2010).

Elbadawi, I. A. and Mwega, F. M. (2000), 'Can Africa's Saving Collapse Be Reversed?', The World Bank Economic Review, Vol. 14 (3), 415 - 443.

Heintz, J. and Ndikumana, L. (2010), 'Is there a Case for Formal Inflation Targeting in SubSaharan Africa?’ African Development Bank Working Paper No. 108.

International Monetary Fund (2005), 'Monetary and Fiscal Policy Design Issues in Low-Income Countries', IMF Policy Paper (August 2005).

Kaminsky, G. L., C. M. Reinhart, and C. A. Vegh (2004), "When It Rains It Pours: Pro-cyclical Capital Flows and Macroeconomic Policies,” NBER Macroeconomics Annual 2004.

Kasekende, L.; Brixiova, Z. and Ndikumana, L. (2010), 'Africa: Africa's Countercyclical Response to the Crisis', Journal of Globalization and Development, Vol. 1 (1), Art. 16.

Khan, M. (2010), 'The Design and Effects of Monetary Policy in Sub-Saharan Africa Countries', Peterson Institute for International Economics Working Paper, No. 10-11. 
Kar, D. \& Cartwright-Smith, D. (2010). Global Financial Integrity: Illicit Financial Flows from Africa: Hidden Resource for Development. Washington, D.C.: Global Financial Integrity. www.gfip.org/index.php?option=com content\&task=view\&id=300\&Itemid=75.

Loayza, N.; Schmidt-Hebel, K. and Serven, L. (2000), 'Saving in Developing Countries: An Overview', The World Bank Economic Review, Vol. 14 (3), 393 - 414.

Ndikumana, L. and Boyce, J. K. (2010). 'New Estimates of Capital Flight from Sub-Saharan African Countries: Linkages with External Borrowing and Policy Options', International Review of Applied Economics, forthcoming.

Reinhart, C. M. and Talvi, E. (1998), 'Capital Flows and Savings in Latin America and Asia: A Reinterpretation', Journal of Development Economics, Vo. 57, 45 - 66.

Serieux, J. (2009), 'Aid and Savings in Sub-Saharan Africa: Should We Worry About the Rising Levels?’ IPC Working Paper No. 50.

Talvi, E., and C. a. Végh (2005), Tax Base Variability and Pro-cyclical Fiscal Policy, Journal of Development Economics.

UNCTAD (2010), 'A Big Public Investment Push Needed in LDCs to meet MDGs', UNCTAD Policy Brief No. 16, September.

Weeks, J. (2010), 'Why Monetary Policy is Irrelevant in Sub-Saharan Africa South of Sahara', CPDR Development Viewpoint, Number 53, (June).

Tong, H. and Wei, S-J. (2009), The Composition Matters: Capital Inflows and Liquidity Crunch During a Global Economic Crisis, IMF Working Paper, No. 09/164. 


\section{DAVIDSON INSTITUTE WORKING PAPER SERIES - Most Recent Papers}

The entire Working Paper Series may be downloaded free of charge at: www.wdi.umich.edu

CURRENT AS OF $1 / 13 / 11$

\begin{tabular}{|c|c|c|}
\hline Publication & Authors & Date \\
\hline $\begin{array}{l}\text { NO. 1008: SUPPORTING AFRICA'S POST-CRISIS GROWTH: THE ROLE OF } \\
\text { MACROECONOMIC POLICIES }\end{array}$ & $\begin{array}{c}\text { Zuzana Brixiova, Leonce } \\
\text { Ndikumana \& Kaouther } \\
\text { Abderrahim }\end{array}$ & Jan 2011 \\
\hline $\begin{array}{l}\text { No. 1007: The Funding \& Efficiency of Higher Education in Croatia \& } \\
\text { Slovenia: A Non-Parametric Comparison w/ the EU \& OECD Countries. }\end{array}$ & $\begin{array}{l}\text { Aleksander Aristovnik and } \\
\text { Alka Obadic } \\
\end{array}$ & Jan 2011 \\
\hline $\begin{array}{l}\text { No. 1006: Public Investment and Fiscal Performance in New EU } \\
\text { Member States }\end{array}$ & Jan Hanousek and Evžen Kočenda & Dec 2010 \\
\hline No. 1005: Is Monetary Policy in New Member States Asymmetric? & Bořek Vašíček & Dec. 2010 \\
\hline $\begin{array}{l}\text { No. 1004: Inflation Targeting in Brazil, Chile \& South Africa: An } \\
\text { Empirical Investigation of Their Monetary Policy Framework }\end{array}$ & Mona Kamal & Nov. 2010 \\
\hline $\begin{array}{l}\text { No. 1003: Assessing Mondragon: Stability and Managed Change in the } \\
\text { Face of Globalization }\end{array}$ & $\begin{array}{l}\text { Saioa Arando, Fred Freundlich, } \\
\text { Monica Gago, Derek C. Jones } \\
\text { and Takao Kato }\end{array}$ & Nov. 2010 \\
\hline $\begin{array}{l}\text { No. 1002: Money Market Integration and Sovereign CDS Spreads } \\
\text { Dynamics in the New EU States }\end{array}$ & $\begin{array}{l}\text { Peter Chobanov, Amine Lahiani } \\
\text { and Nikolay Nenovsky }\end{array}$ & Oct 2010 \\
\hline No. 1001: Modeling transition in Central Asia: the Case of Kazakhstan & $\begin{array}{l}\text { Gilles DUFRENOT, Adelya } \\
\text { OSPANOVA, Alain SAND- } \\
\text { Zantman }\end{array}$ & Oct 2010 \\
\hline $\begin{array}{l}\text { No.1000: Unlocking Productive Entrepreneurship in Ethiopia: } \\
\text { Which Incentives Matter? }\end{array}$ & $\begin{array}{l}\text { Zuzana Brixiova \& } \\
\text { Emerta Asaminew }\end{array}$ & Oct 2010 \\
\hline No.999: Price convergence and market integration in Russia & Konstantin Gluschenko & Sept 2010 \\
\hline $\begin{array}{l}\text { No. 998: Bank Efficiency in Transitional Countries: Sensitivity to } \\
\text { Stochastic Frontier Design }\end{array}$ & Zuzana Irsova & Sept 2010 \\
\hline $\begin{array}{l}\text { No. 997: EU Enlargement and Monetary Regimes from the Insurance } \\
\text { Model Perspectives }\end{array}$ & Nikolay Nenovsky & June 2010 \\
\hline $\begin{array}{l}\text { No. 996: Which Foreigners are Worth Wooing? } \\
\text { A Meta-Analysis of Vertical Spillovers from FDI }\end{array}$ & $\begin{array}{c}\text { Tomas Havranek and } \\
\text { Zuzana Irsova }\end{array}$ & June 2010 \\
\hline $\begin{array}{l}\text { No. 995: Environmental Regulation and Competitiveness: } \\
\text { Evidence from Romania }\end{array}$ & $\begin{array}{c}\text { Guglielmo M. Caporale, } \\
\text { Christophe Rault, Robert Sova \& } \\
\text { Anamaria Sova }\end{array}$ & June 2010 \\
\hline $\begin{array}{l}\text { No. 994: Pollution Abatement And Control Expenditure In Romania: } \\
\text { A Multilevel Analysis }\end{array}$ & $\begin{array}{c}\text { Guglielmo M. Caporale, } \\
\text { Christophe Rault, Robert Sova \& } \\
\text { Anamaria Sova }\end{array}$ & June 2010 \\
\hline $\begin{array}{l}\text { No. 993: Do Innovative Workplace Practices Foster Mutual Gains? } \\
\text { Evidence From Croatia }\end{array}$ & Derek Jones and Srecko Goic & May 2010 \\
\hline $\begin{array}{l}\text { No. 992: Firm And Employee Effects Of An Enterprise Information } \\
\text { System: Micro-Econometric Evidence }\end{array}$ & $\begin{array}{l}\text { Derek Jones, Panu Kalmi } \\
\text { and Antti Kauhanen }\end{array}$ & June 2010 \\
\hline $\begin{array}{l}\text { No. 991: Catching-up and inflation in Europe: Balassa- } \\
\text { Samuelson, Engel's Law and other Culprits }\end{array}$ & Balázs Égert & June 2010 \\
\hline $\begin{array}{l}\text { No. 990: UNLOCKING PRODUCTIVE ENTREPRENEURSHIP IN AFRICA'S LEAST } \\
\text { DEVELOPED COUNTRIES }\end{array}$ & Zuzana Brixiova & June 2010 \\
\hline $\begin{array}{l}\text { No. 989: The VARying Effect of Foreign Shocks in Central \& Eastern } \\
\text { Europe }\end{array}$ & $\begin{array}{l}\text { Rebeca Jimenez-Rodriguez, } \\
\text { Amalia Morales-Zumaquero } \\
\text { \& Balazs Egert }\end{array}$ & May 2010 \\
\hline $\begin{array}{l}\text { No. 988: Implications of Bank Ownership for the Credit Channel of } \\
\text { Monetary Policy Transmission: Evidence from India }\end{array}$ & $\begin{array}{l}\text { Sumon K. Bhaumik, Vinh Dang } \\
\text { and Ali M. Kutan }\end{array}$ & May 2010 \\
\hline $\begin{array}{l}\text { No. 987: Mother or motherland: Can a government have an impact on } \\
\text { educational attainment of the population? Preliminary evidence from } \\
\text { India }\end{array}$ & $\begin{array}{l}\text { Sumon Kumar Bhaumik and } \\
\text { Manisha Chakrabarty }\end{array}$ & May 2010 \\
\hline $\begin{array}{l}\text { No. 986: Does FDI spur innovation, productivity and knowledge sourcing } \\
\text { by incumbent firms? Evidence from manufacturing industry in Estonia }\end{array}$ & Priit Vahter & April 2010 \\
\hline
\end{tabular}

